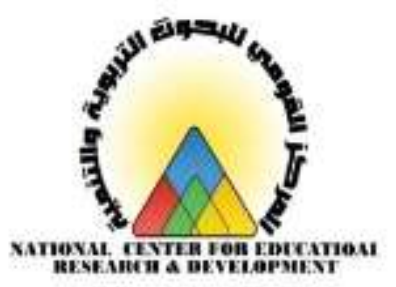

\title{
دور الأنشطة الطلابية في تعزيز ثقافة العمل التطوعي لدى طالبات جامعة التصيم: دراسة هيدانية
}

\author{
إعلاد الباحثني
}

د. حصة بنت حمود البازعي

$$
\text { كلية التربية }
$$

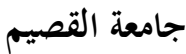

أ. آسيه بنت عبدالله اللحيدان

$$
\text { كلية التربية }
$$

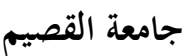

$$
\begin{aligned}
& \text { الناش } \\
& \text { المىز التومي للبحوث التربوتتصالثميتهالتاهـة } \\
& \text { جمهورية مصر العربية }
\end{aligned}
$$

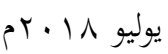




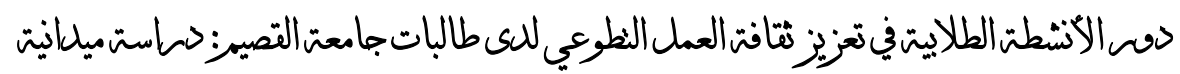

. $\Sigma \Gamma \leqslant$.

البحثث التريوي 


\section{المركن القومي للبحوثالتهبيةوالنمية}

\section{دور الأنشطة الطلابية في تعزيز ثقافة العمل التطوعي لدى طالبات جامعة القصيم: دراسة هيدانية}

\section{ملفمر الدراسة :}

هدفت الدراسة إلى التعرف على دور الأنشطة الطلابية في تعزيز تقافة العمل التطوعي لدى طالبات جامعة القصيم، كذللك التعرف على الفروق ذات الدلالة الإحصائية في استجابات أفراد العينة حول دور الأنشطة الطلابية في تعزيز نقافة

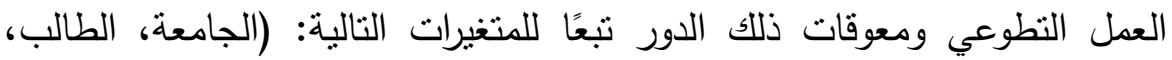
الموقع). ومتل مجتمع الدراسة طالبات جامعة القصيم المنتظمات بمختلف التخصصات والمستويات الدراسية، وتوصلت الدراسة إلى مجموعة من النتائج منها:

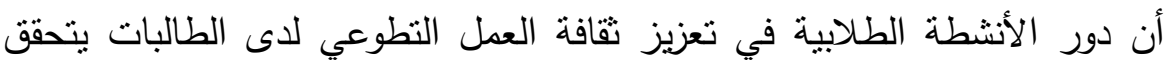

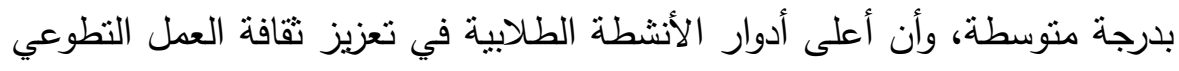

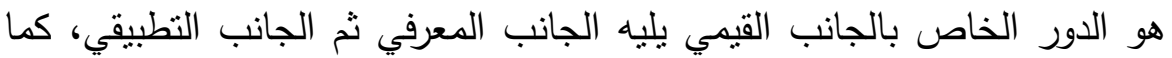
نوصلت الدراسة إلى وجود معوقات تحول دون تحقيق الأنشطة الطلابية في جامعة القصيم لدورها فى تعزيز نقافة العمل التطوعي لدى طالبات الجامعة متوسطها كبيرة

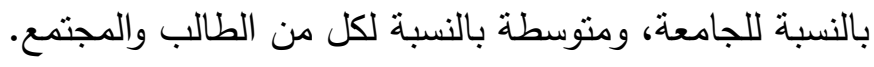




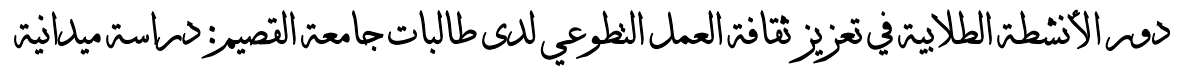

The role of student activities in the promotion of a culture of volunteering among students of the University of Qassim: A field study.

\author{
Mrs.Assia Bint Abdealla Alahdaan. \\ Dr. Hosaa Bint Hamoud Albzaay \\ Faculty Education \\ University of Qassim
}

\title{
Abstract
}

The study aimed to identify the role of student activities in the promotion of a culture of volunteering among students of the University of Qassim, as well as detect differences in the responses of the sample according to the following variables: college, school year, the practice of voluntary work. Qassim University female students were represented in study population in terms of the various disciplines and grade levels. The study found a range of results, including that there were statistically significant differences in student responses to the role of student activities in the promotion of a culture of volunteering in the aspects - cognitive, moral, practical, and total score The study also found obstacles that prevent achieving student activities at El Qaseem University as a result of its role in promoting the culture of volunteer work among university students, which has a very high average for the university and a medium one for both students and society. 


\section{المركن القومي للبحوث التبويةوالتنمية}

\section{دور الأنشطة المطلابية في تمريّز ثقانة العمل التطومي لثى طالبات جامعة القميم: دراسة ميد|نية إعلادالباحثني}

د. حصة بنت حمود البازعي

كلية التربية

جامعة القصيم
أ. آسيه بنت عبدالله اللحيدان

كلية التربية

جامعة القصيم

الاقدهمة:

تسعى سياسة دول العالم المتقدم إلى تكثيف الجهود وبث الوعي من أجل تحقيق خدمة الأفراد لمجتمعاتهم، وترسيخ مبادئ التكافل الاجتماعي وتأصيله من خلال المساهمة في الأعمال التطوعية، لما لذلك من أثر إيجابي في تحقيق التتمية والازدهار للفرد والمجتمع، ورغبة منها في الوصول إلى أعلى درجات التطور والرقي التي وأسمى مبادئ الترابط والتكافل.

حيث ترتبط حركة المجتمع أو ركوده بمستوى الثقافة لديه، فإذا ساد المجتمع ثقافة إيجابية وفعالة وواعية فسيكون مجتمعًا حيويًا ومنتجًا ومتقدمًا، وإذا ما حلت عليه ثقافة سلبية فسيتحول المجتمع إلى حالة من الركود والتخلف، وثقافة التطوع ماليه جزء من مفهوم الثقافة بالمعنى العام وإيجاد مثل هذه الثقافة في أي مجتمع يسهم في

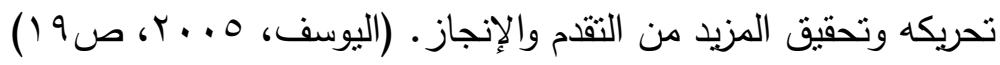
ولكي يحقق العمل التطوعي نجاحًا بارزًا فإنه يعتمد في ذللك على نوافر المورد

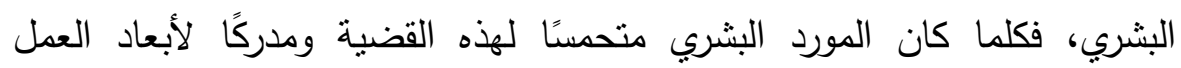
التطوعي كان باستطاعته تحقيق نتائج إيجابية وواقعية. (التويجري، سا ــr، 


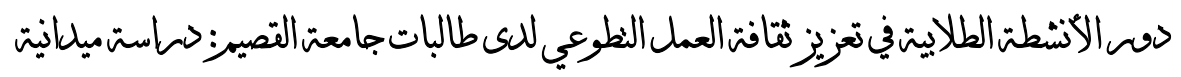

وانطلاقًا من العلاقة التي تربط بين النطوع والمورد البشري، يمكن القول بأن

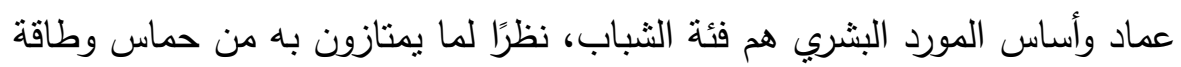

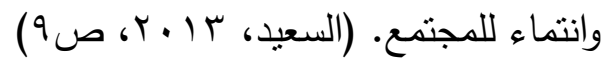

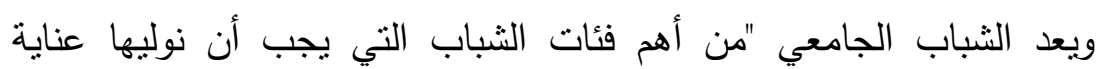

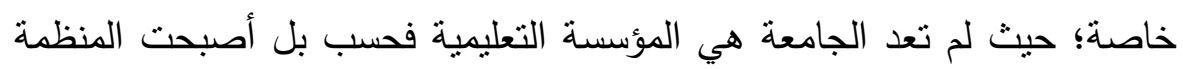

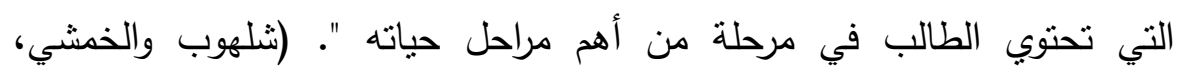

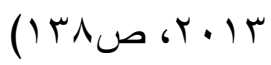

وتعتبر عمادة شؤون الطلاب من العمادات المساندة في الجامعات والتي

تتضمن داخلها عدد من الإدارات منها إدارة مسئولة عن الأنشطة الطلابية.

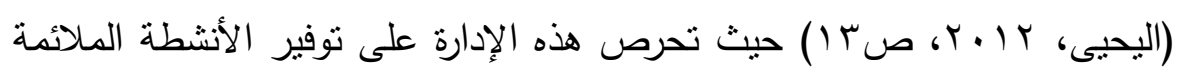

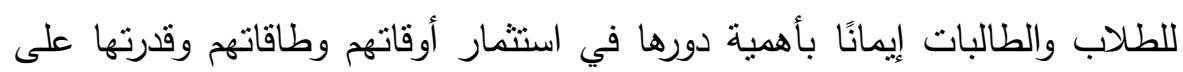

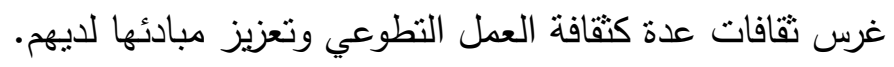

\section{مشكلة الدراسة وتساؤلاتها:}

أجريت عدد من الدراسات على بعض طلاب الجامعات في المملكة، منها

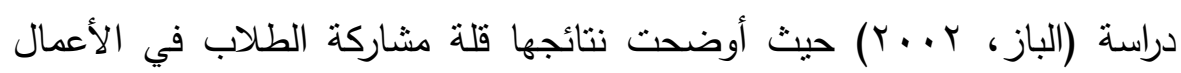

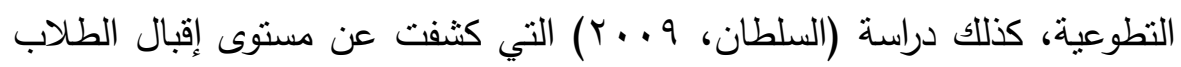

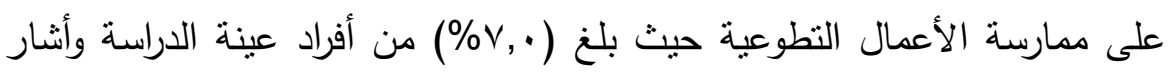

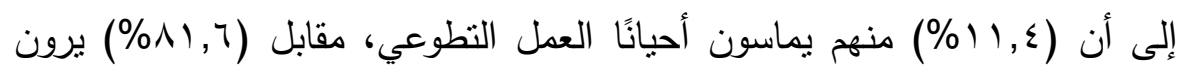

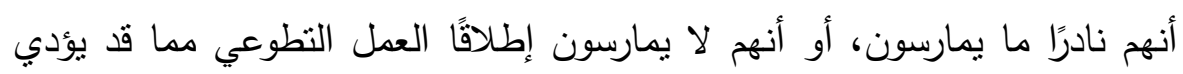

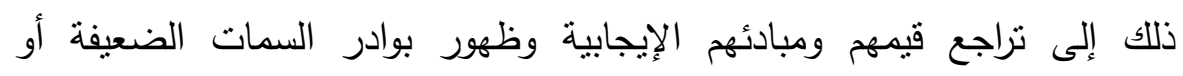

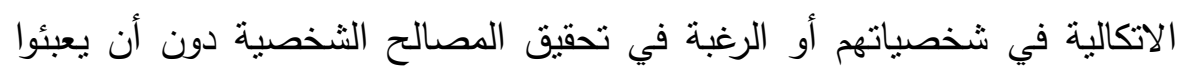

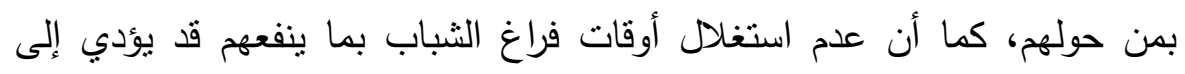




\section{المركن القومي للبحوث التبويةوالتنمية}

انشغالهم بأمور سلبية وغير مرغوبة تضر بهم وبمجتمعاتهم، لذا بيتحسن إثنالهم

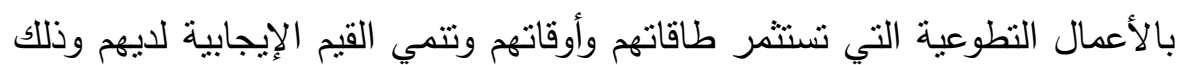
يتت عبر الأنشطة والبرامج التطوعية الداخلية والخارجية التي تقيمها وتوفرها المؤسسات التعليمية المختلفة لهم. وفي ضوء ذلك تتحدد مشكلة الدراسة في الإجابة عن التساؤل الرئيسي التالي:

ما دور الأنشطة الطلابية في تعزيز ثقافة العمل التطوعي لاى طالبات

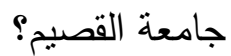

ويتفرع من السؤال الرئيس الأسئلة التالية:

1- ما واقع دور الأنشطة الطلابية بجامعة القصيم في تعزيز ثقافة العمل

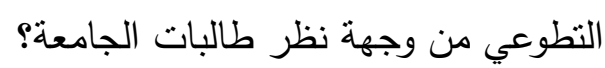

r- ما المعوقات التي تحول دون تحقيق الأنشطة الطلابية في جامعة القصيم

لدورها في تعزيز ثقافة العمل التطوعي من وجهة نظر طالبات الجامعة؟

\section{أهداف الدراسة:}

1- التعرف على واقع دور الأنشطة الطلابية بجامعة القصيم في تعزيز ثقافة

$$
\text { العمل التطوعي لدى طالبات الجامعة. }
$$

r- الكثف عن المعوقات التي تحول دون تحقيق الأنشطة الطلابية لدورها في

$$
\begin{aligned}
& \text { تعزيز ثقافة العمل التطوعي لدى طالبات الجامعة. } \\
& \text { أهمبة الدراسة: }
\end{aligned}
$$

- تنتاول الدراسة موضوعًا حيويًا يتعلق بدور الأنشطة الطلابية في تعزبز ونشر

$$
\text { ثقافة العمل التطوعي. }
$$




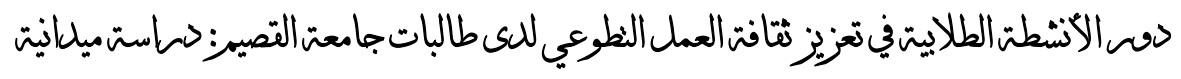

- تستمد الدراسة أهيتها من الفئة التي تتتاولها وهي الثباب الجامعي، والحاجة إلى إدماجه في تتمية مجتمعه والإفادة الإيجابية من وقت فراغه.

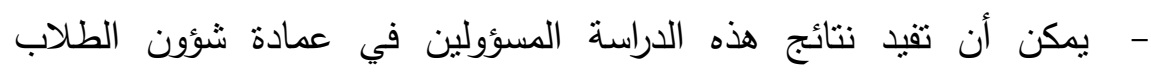
بالجامعة في تطوير دور الأنشطة الطلابية في تعزيز نقافة العمل التطوعي. هصطاح الدات الدراسة: - الدور (the role)

يعرف الدور بأنه "نمط السلوك المتوقع من الثخص الذي يشغل وضعًا

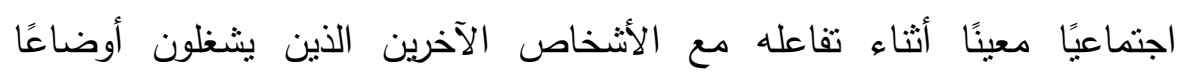

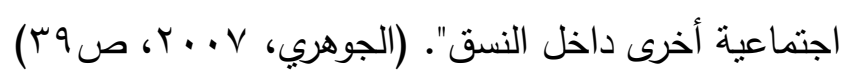
- الأنشطة الطلابية (Students' activities):

تعرف الأنشطة الطلابية "خطة مدروسة ووسيلة لإثراء المنهج تنظمها

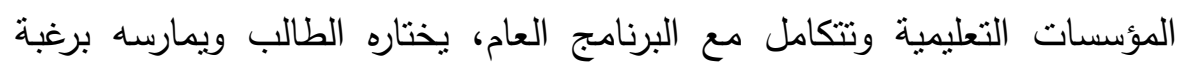

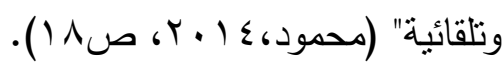

$$
\begin{aligned}
& \text { - }
\end{aligned}
$$

تعرف بأنها "قاعدة المعلومات والمعارف المشتركة للمجتمع التي يعتمد عليها

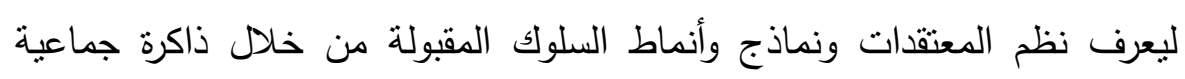

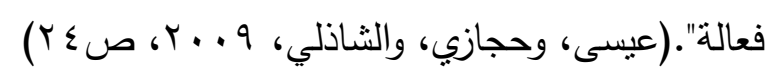
- - نقافة العمل التطوعي (Volunteering culture): تعرف بأنها "الكل المركب من الدفاهيم والأفكار والمبادئ والقيم والنظم

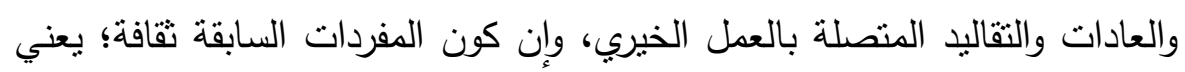

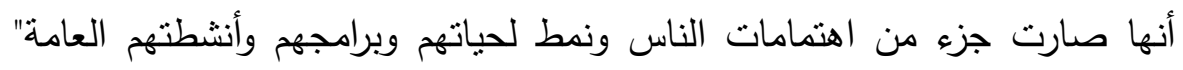

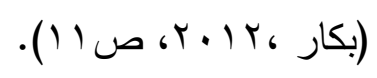
.$\varepsilon \varepsilon \cdot$. البحث التربوي 
- الدراسات المتعلقة بالأنثطة الطلابية:

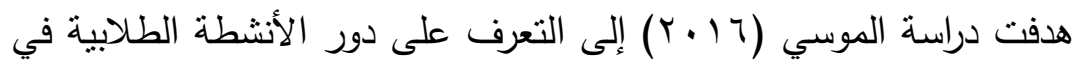

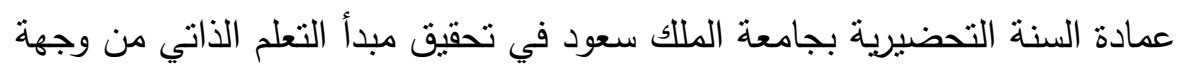
نظر الطالبات، وذلك من خلال معرفة نوعية الأنشطة المطبقة ومدى تحقيقها

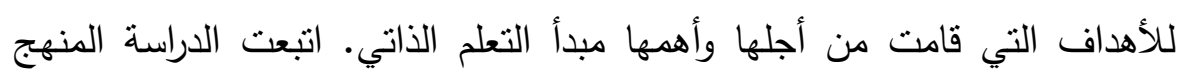

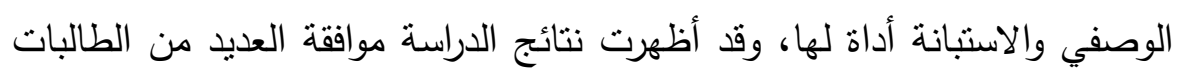

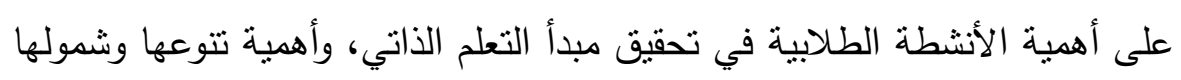

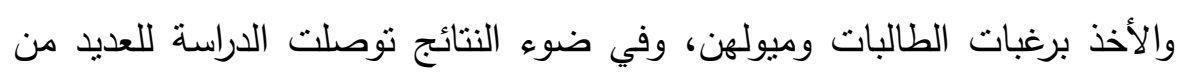

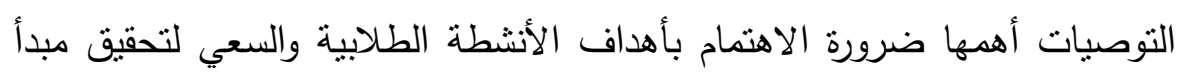

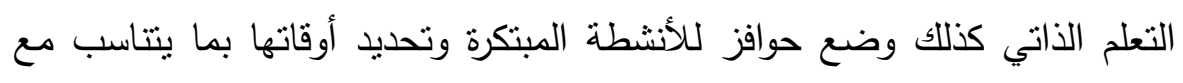

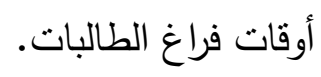

وهدفت دراسة مزيو (ع ا ب. إلى معرفة الدور التزبوي الذي يمكن للأنشطة

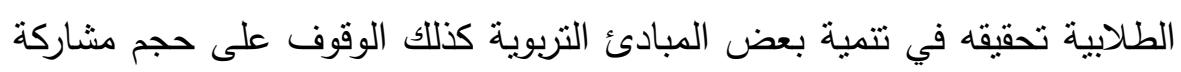

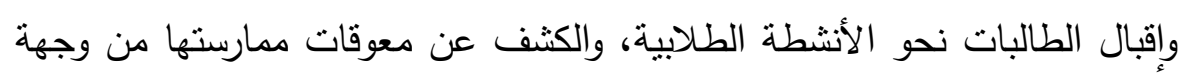

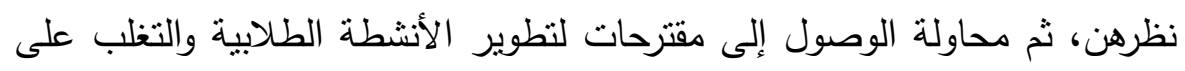

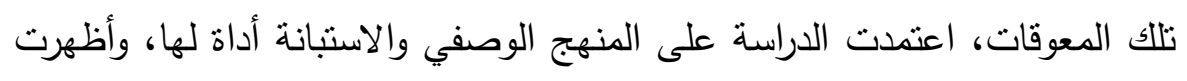

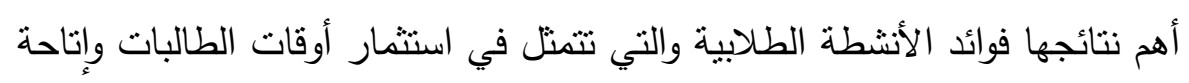

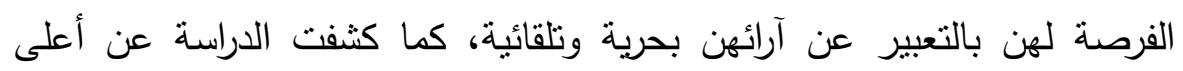

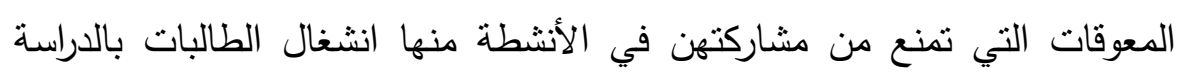

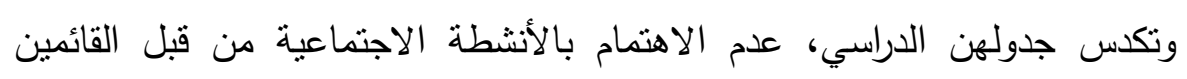




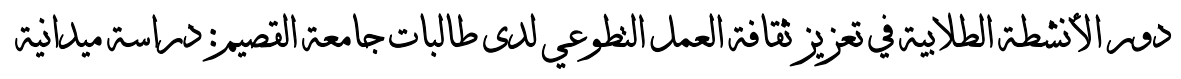

عليها، كما أثنارت الدراسة إلى عدد من المقترحات الهامة التي تسهم في تطوير الأنشطة منها ضرورة وضع النشاط الطلابي في الاعنبار عند التخطيط للتعليه، العطل على زيادة الوعي بالأنثطة الطلابية وأهينتها.

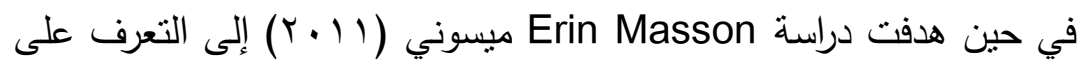
التأثيرات الإيجابية لممارسة الأنشطة اللاصفية على الطلاب، وقد اعتدت الدراسة

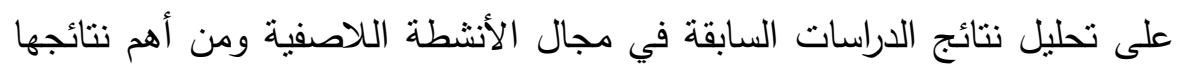

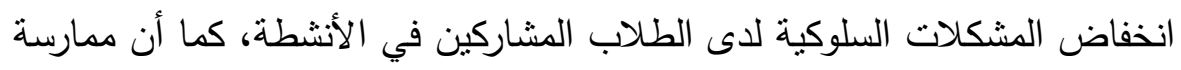

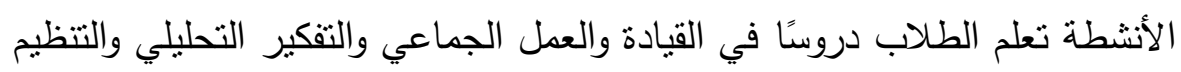

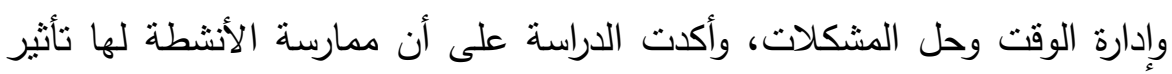
إيجابي على الجوانب الاجتماعية للطلاب.

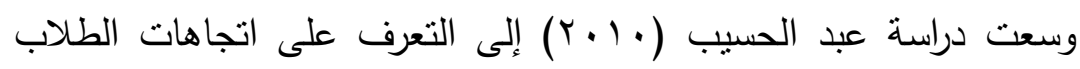

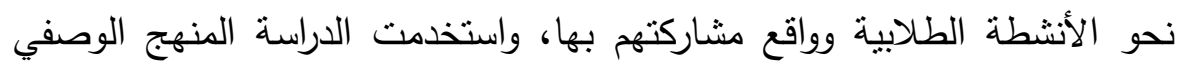

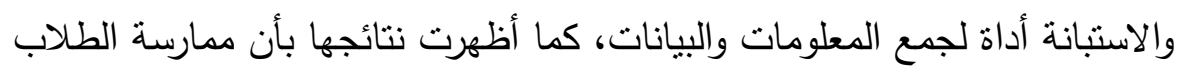

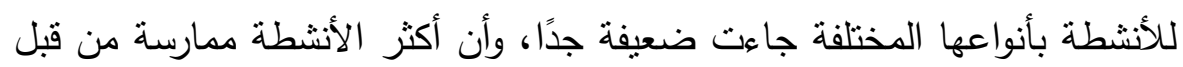

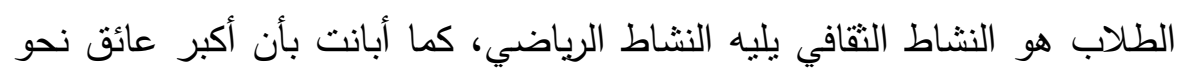

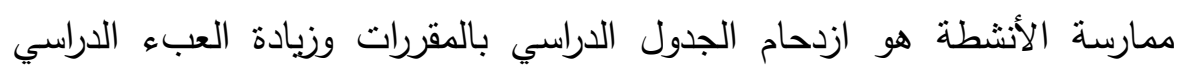
عليهم، كذلك قلة الحوافز المادية المقدمة للطلاب المشاركين بالأنشطة الطلابية.

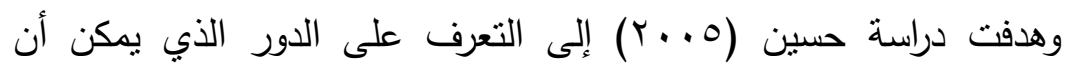

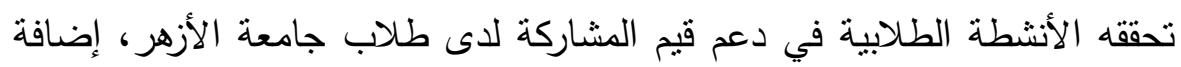

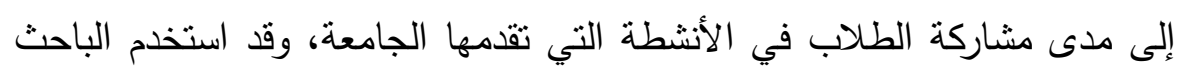

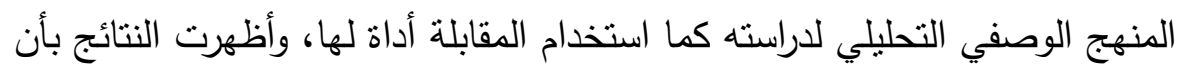




\section{المركن القومي للبحوث التبويةوالتنمية}

الجنس كمتغير يؤثز على حجم المشاركة حيث اتضح أن الذكور أكثر من البنات في حجم المشاركة بالأنشطة الطلابية. - - الدراسات المتعلقة بالعمل التطوعي:

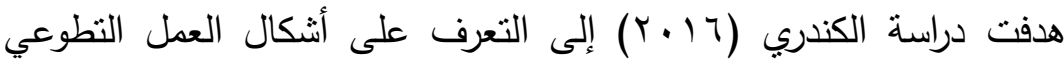
وأهم مجالاته إضافة إلى الكثف عن واقع ثقافة العمل التطوعي لدى طلبة كلية التربية الأساسية، واعتمد الباحث في دراسته على المنهج الوصفي والاستبانة أداة لدراسته وقد أوصت الدراسة بعدد من التوصيات منها ضرورة نشجيع الثباب عامة وطلاب الكلية خاصة على ممارسة العمل التطوعي، أهمية التركيز على مفاهيم العمل التطوعي ودوره التنموي ضمن المناهج الدراسية في جميع المراحل الدراسية، كذلك توعية طلاب الكلية بقيمة ودور العمل التطوعي من خلال عقد الندوات والملتقيات للتباحث حول حال العمل التطوعي.

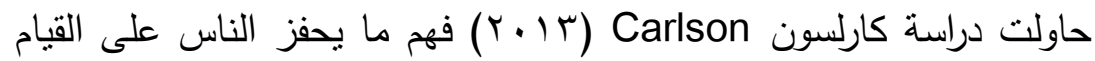
بالأعمال التطوعية وإلى أي مدى قد تساعد هذه المعلومات بتجنيد المتطوعين

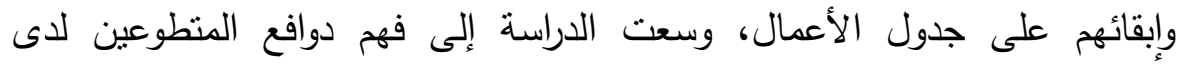
الجمعية الثرفية "فاي كابا فاب" والمقارنة بين المتطوعين المحليين والوطنيين وإذا ما كان هناك اختلاف في الدوافع على أساس الخصائص الديموغرافية، والوظائف التطوعية والاحترافية، ومراتب هيئة التدربس، واستخدمت الدراسة خطة البحوث المسحية وشملت (90 ب 1) فردًا، عضوًا كان أو غير عضو في الجمعية الثرفية، وكان الغرض من أطروحة الدكتوراه هذه توسيع نطاق العمل على النظرية النفعية ومدى ارتباطها بتحريك المتطوعين من خلال فهم محاولة ما يحفز الناس على القيام بعمل تطوعي، وأثنارت نتائج الدراسة إلى وجود اختلافات في دوافع العمل التطوعي 


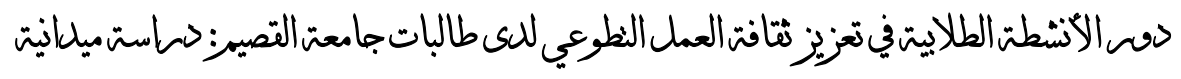

كمرك للفئة المهنية، ووجود اختلافات في عوامل دفع العمل التطوعي كموجه لرتبة هيئة الندريس.

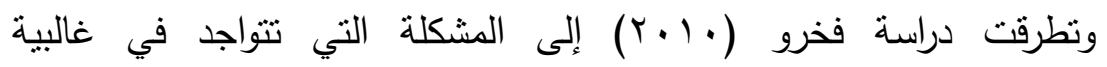

المجتمعات العربية وهي ضعف ثقافة العمل التطوعي، والوصول إلى الكيفية والسبل

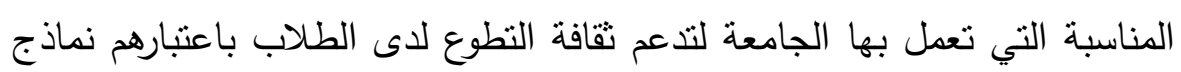

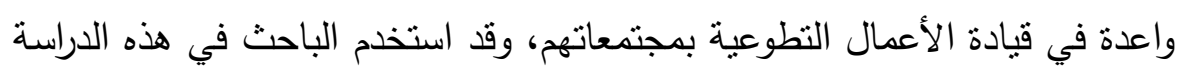

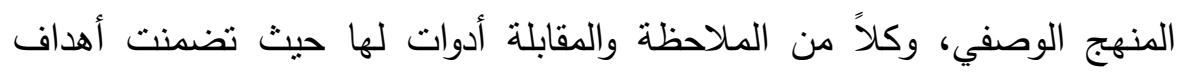

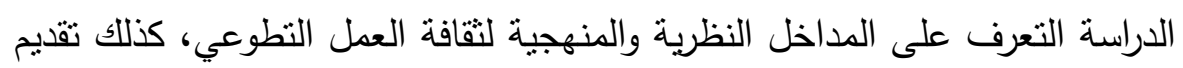
تصور مقترح لتعزيز دور الجامعة في بناء ثقافة العمل النطوعي لاى الطلاب،

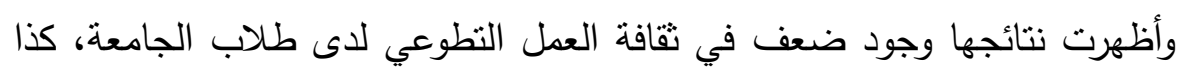

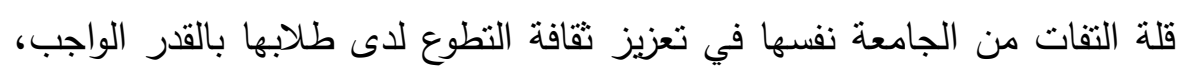

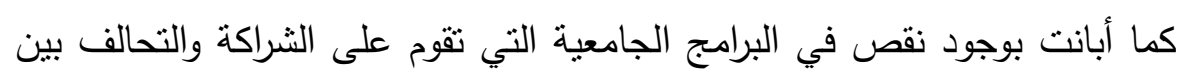

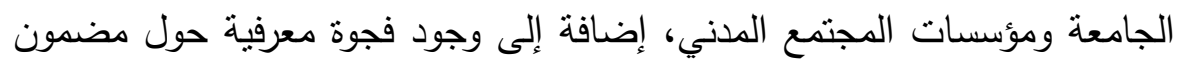
ثقافة التطوع لدى الطلاب تتعلق بغياب الوعي بمكانة العمل النطوعي في الدين الندان الإسلامي.

وسعت دراسة السلطان (9 . . ب) إلى الكثف عن اتجاهات الثباب الجامعي

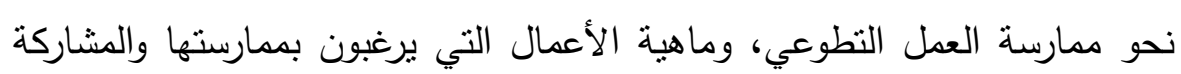

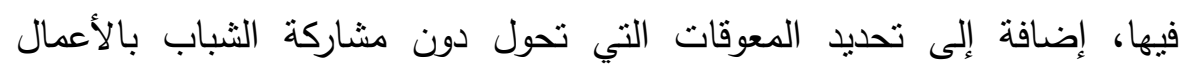
النطوعية، واستخدم الباحث في دراسته مدخلين من مداخل المنهج الوصفي هما:

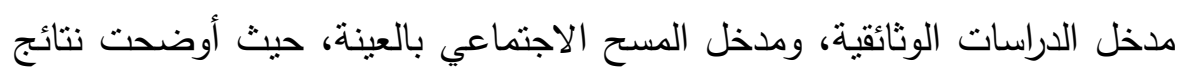

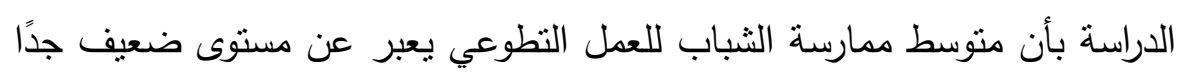
كما أظهرت بأن هناك اتجاهات إيجابية نحو العمل التطوعي حيث جاءت التئ مساعدة 


\section{المركن القومي للبحوث التبويةوالتنمية}

ورعاية الفقراء والمحتاجين، ثم زيارة المرضى، يليها المشاركة في الإغاثة الإنسانية، ورعاية المعاقين والحفاظ على البيئة ومكافحة المخدرات والتذخين، في صدر المجالات التي يرغب الثباب الجامعي المشاركة فيها، كما أظهرت النتائج عدم وجود فروق ذات دلالة إحصائية بين اتجاهات الثباب الجامعي نحو محاور ممارسة العمل التطوعي، والمعوقات التي تحول دون مشاركتهم، والأساليب والآليات اللازمة لتفعيل مشاركة الثباب في العمل التطوعي تعزى إلى أي من متغير الكلية

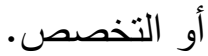

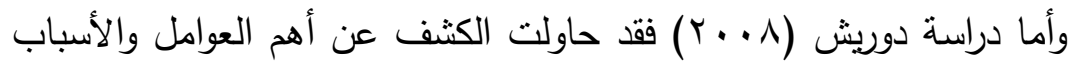
(الاقتصادية- الذاتية- المجتمعية والثقافية- الأسرية) التي تعوق من مشاركة الثباب الجامعي في العمل التطوعي، كذللك تحديد مفهوم العمل التطوعي لدى الثباب، واستخدمت الباحثة المنهج المسحي الاجتماعي والاستبانة أداة لجمع البيانات، وقد نتج عن دراستها بيان حول أبرز المعوقات منها أن أسلوب تنشئة الثباب لا تحثهم على المشاركة بالأعمال النطوعية، كما أن اهتمام الثباب بالدراسة

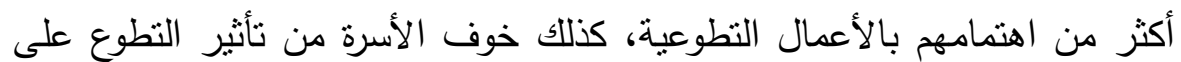
مستقبل أبنائها وعدم توفر جوانب مادية يمكن التبرع من خلالها للمؤسسات الخيرية، وتفضيل الشباب الأعمال التي تدر عليهم دخلاً.

\section{الأنشطة الطلابية:}

أصبح التعليم الجامعي اليوم عبارة عن منظومة متكاملة تحرص على تتمية الطلاب من خلال غرس القيم التي تسمو بأنفسهم ونتري أفكارهم ومعارفهم، وذللك من خلال وسائلها ومناهجها الدراسية وأنشطتها الطلابية المتتوعة التي تطرحها الجامعة، وسيتم توضيح عدد من الموضوعات المتعلقة بالأنشطة الطلابية منها: 


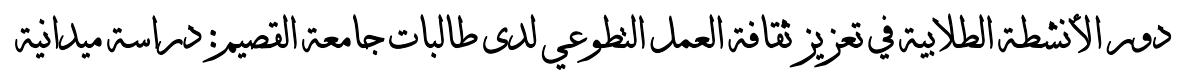

مراحل تطور الأنشطة الطلابية، نبذة عامة عن الأنشطة الطلابية في المملكة، نبذه عامة عن الأنشطة الطلابية في جامعة القصيم، أهمية الأنشطة، ومعايير نجاحها. هراحل تطور الأنشطة الطلابية:

إن الاهتمام بأمر الأنشطة لا يعد أمرًا جديدًا فقد كانت القرون القديمة

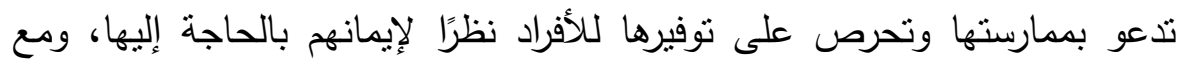
تطور العصور وتغير المجتمعات ازداد هذا الاحتياج ونتيجة لهذه التغيرات

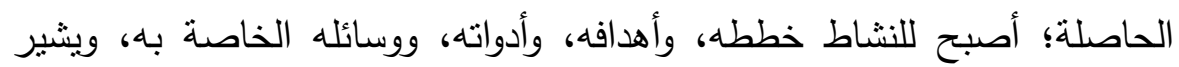

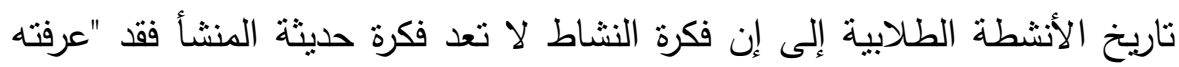

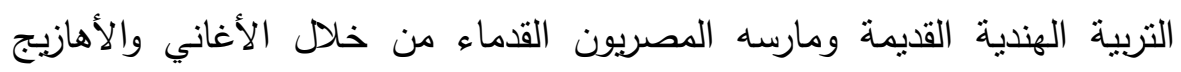

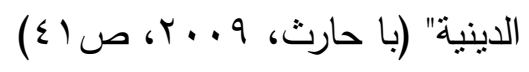

كما ظهرت في زمن اليونانيون والرومان ممارسات متعددة للأنشطة

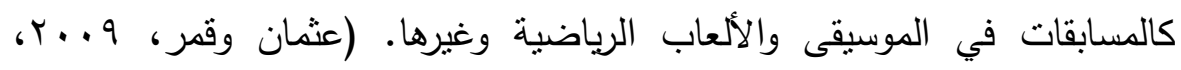
صنr)

ومارس العرب أيضًا في أيام الجاهلية والإسلام مجموعة من النشاطات المختلفة حيث برعوا في بعض الفنون كالرماية والمبارزة وركوب الخيل والسباحة،

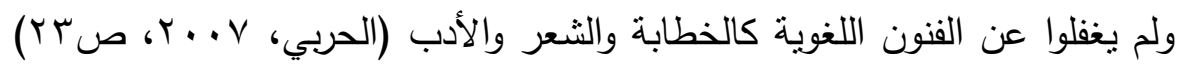

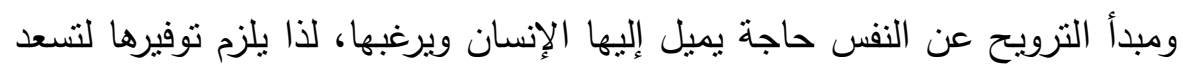
النفس وتتهيأ لمواجهة الحياة وصعابها.

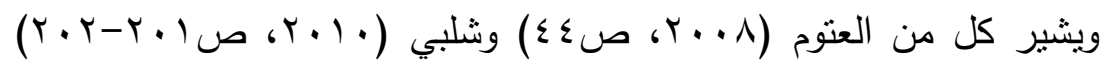

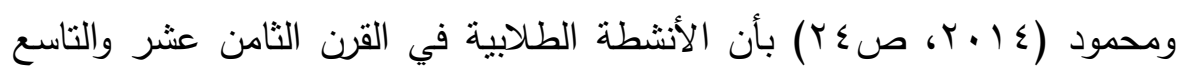

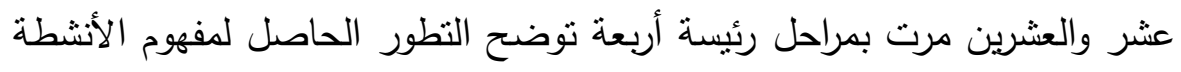

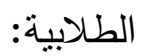




\section{المركن القومي للبحوث التبويةوالتنمية}

المرحلة الأولى: وهي مرحلة التجاهل حيث لم يظهر أي اهتمام بإلحاق الطلاب لممارسة الأنشطة، فقد كان تركيزهم منصبًا على النواحي العقلية وحشو الأذهان بالمعلومات، وسبب هذا التجاهل هو النظر لها على أنها درب للترف مرت هذه الفترة خلال القرن الثامن عشر. المرحلة الثانية: معارضة الأنشطة الطلابية لكونها تهدد الجو الأكاديمي، فالتحاق الطلاب بها سيؤول إلى عدم اهتمامهم بالمحتوى العلمي وضعف التحصيل الدراسي، مما دعا إلى معارضتها ورفضها وذللك في الربع الأخير من القرن الثامن عشر

المرحلة الثالثة: مع نهايات القرن التاسع عثر أصبح هناك قبول للأنشطة الطلابية بعد الإهمال والرفض السابق لها، إلا أنها قبلت خارج إطار المنهج واعتبرت جزءًا من وظيفة المدرسة حيث أظهر الطلاب وأولياء الأمور اهنمامًا واضحًا بها.

المرحلة الرابعة: بقدوم القرن العشرين أصبح الاهتمام بالأنشطة أمرًا واضحًا وذلك تبعًا لتغير النظرة التربوية الحديثة حيث اعتبرت الأنشطة جزءًا من المنهج الدراسي، ودعت إلى تتمية جوانب الطلاب من النواحي المختلفة له وعدم التركيز على جانب دون الآخر، والأخذ بعين الاعتبار رغبات وميول الطلاب في اختيار الأنشطة.

\section{تطور الأنشطة الطلابية في المملكة العربية السعودية:}

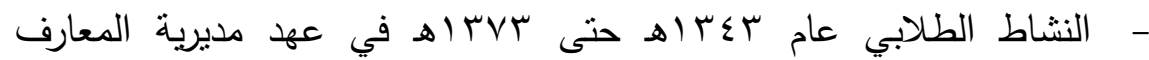
العامة.

حرص ملوك وأمراء المملكة على رعاية الأنشطة الطلابية وحضور فعالياتها المقامة دعمًا منهم للعلم والتعلم وتعزبزًا لأبنائهم الطلاب؛ ومن أبرز الأنشطة في 


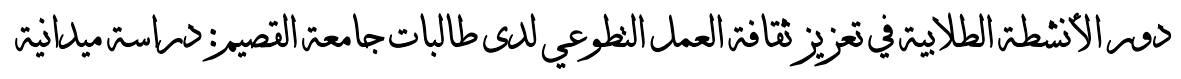

تلكك الفترة حضور الملك فيصل حفلاً رياضيًا نظمته مديرية المعارف وقد أقيم في مكة المكرمة، كما تم تكوين أول فرقة كثفية في عام بحس إه إضافة إلى إعادة

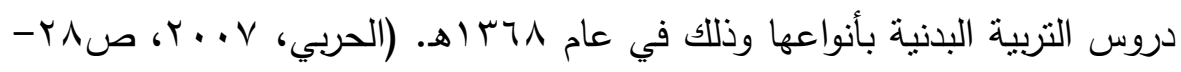

- - النشاط الطلابي عام rV إه في عهد وزارة المعارف وحتى الآن. تعرف وزارة المعارف اليوم بوزارة التعليم ويعتبر إيجاد منل هذه الوزارة في ذلك الوقت نقلة مهمة في تاريخ التعليم السعودي، حيث شهدت تلك الفترة تغيرات إيجابية في كافة المجالات التربوية من ضمنها الاهنمام بالأنشطة الطلابية والحرص على لى توفيرها للطلاب، بعدها عملت الوزارة على إنشاء إدارة التربية والنشاط الاجتماعي.

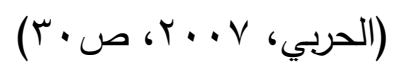

والتي تعمل على التخطيط والإثراف وتتفيذ البرامج والانشطة الاجتماعية، وفي عام اN1/ اهـ تطورت لتصبح بمسمى آخر وهو الإدارة العامة لرعاية الثباب وقد

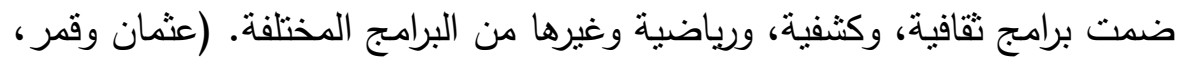

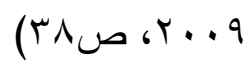

وفي سنة ا •ـ اهـ سميت بالإدارة العامة للنشاط المدرسي وقد أصدر الوزير إحداث وظيفة وكيل وزارة مساعد لشؤون الطلاب وترتبط به الإدارات النالية

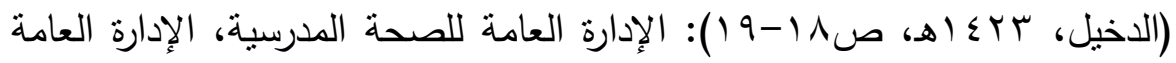
للنشاط الطلابي، الإدارة العامة للامتحانات، إدارة المعادلات. كما تم اعتماد هيكل عام لإدارة النشاط حيث تضمن:

إدارة النشاط الاجتماعي، إدارة النشاط الكثفي، إدارة النشاط المسرحي، إدارة النشاط العلمي والأدبي، إدارة النشاط الفني والمهني، إدارة النشاط الرياضي. 


\section{المركن القومي للبحوث التبويةوالتنمية}

وفي عام I ا أه تم الإقرار بتسميته الإدارة العامة للنشاط الطلابي، جاء

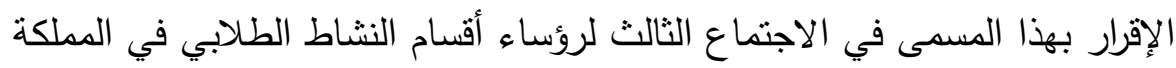
وذلك تبعًا للمفهوم الثامل الذي يتضمن الممارسات الطلابية داخل المدرسة وخارجها، واشتملت الإدارة العامة للنشاط الطلابي على تشكيل إداري جديد شمل

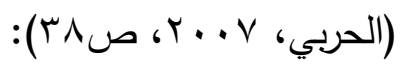

إدارة النشاط الاجتماعي، إدارة النشاط الكثفي، إدارة النشاط العلمي، إدارة النشاط الثقافي، إدارة النشاط الرياضي، إدارة النشاط الفني والمهني، إدارة الميزانية والمتابعة، إدارة الثؤون الإدارية.

وتترف الآن الإدارة العامة للنشاط الطلابي على أوجه النشاط المختلفة وتقوم

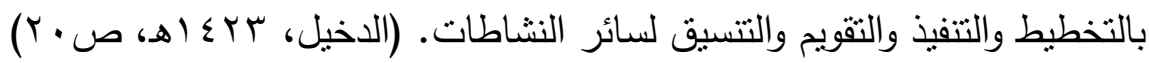
وفيما يخص التعليم الجامعي في الوقت الحالي فإن عمادة شؤون الطلاب في الجامعات تشرف على النشاط الطلابي وتعمل على تقديم كافة الخدمات الطلابية. "فهي الجهة ذات العلاقة المباشرة بالطلاب والقائمة على رعايتهم ومباشرة نشاطاتهم بأنواعها المتعددة، وعلى عاتقها تقع مسؤولية إعدادهم تربويًا، واجتماعيًا، وثقافيًا،

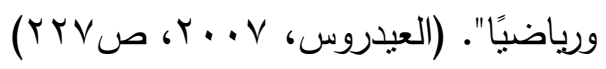

ومن خلال ما سبق يتضح لنا حرص المملكة العربية السعودية على رفع مستوى التعليم ودعم أبنائها وتحفيزهم على تلقيه، ومواكبة التغيرات المتسارعة وتطوير كل ما فيه مصلحة للعلم والمتعلم وذلك حرصًا منها على تخريج جيل بمتاز بقدر عالٍ من العلم والمعرفة ويحرص على خدمة دينه وبلده وأبناء مجتمعه.

\section{نبذه عاهة عن الأنشطة الطلابية في جامهة القصيم:}

تعد جامعة القصيم إحدى الجامعات الحكومية الثاملة في المملكة، والتي تضم عدد كبير من التخصصات في المجالات المختلفة الثرعية والإنسانية والهندسية 


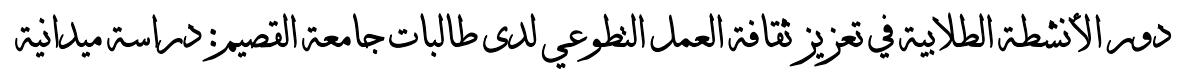

والصحية، وتقوم بمنح جميع الدرجات العلمية بعد المرحلة الثانوية، أنشئت الجامعة

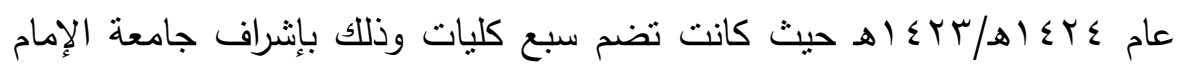

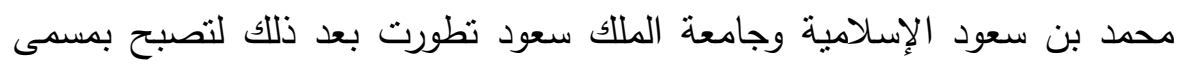

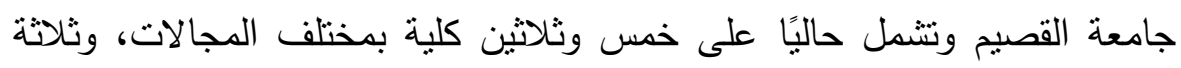
عشر عمادة مساندة. (جامعة القصيم، د.ت) ومن ضمن هذه العمادات عمادة شؤون الطلاب والتي تهنم بخدمة الطلاب من جميع الجوانب وتحرص على دعمهم وإعانتهم على استكمال سير دراستهم.

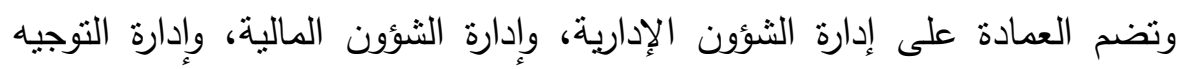

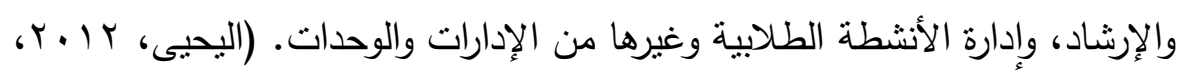

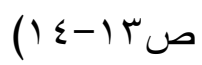

وتسعى إدارة الأنشطة الطلابية إلى إعداد المواطن المؤمن الذي بسعى لبناء

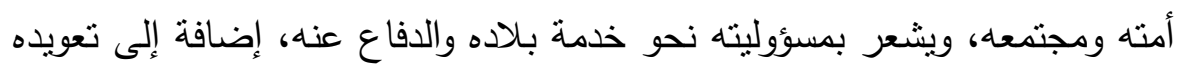

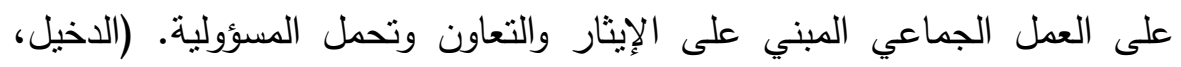

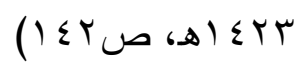
كما تحرص الجامعة على دعم الطلاب من خلال توفير برامج الأنشطة

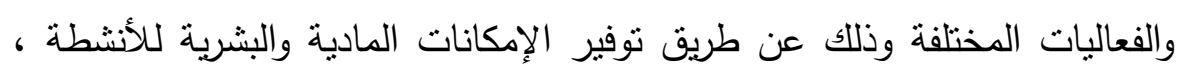

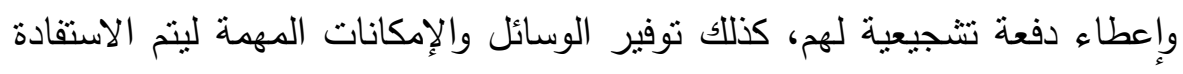
من أوقات الطلاب بما ينفعهم وبما يعزز من قدراتهم ويكسبهم العادات الإيجابية.

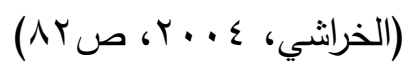
وتؤكد إدارة الأنشطة الطلابية بجامعة القصيم على أن "الطالب هو المحور

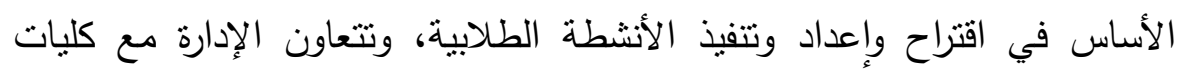

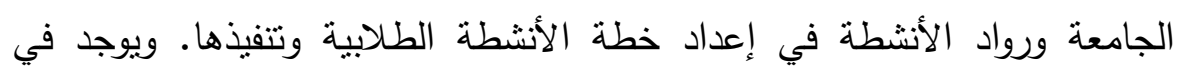

$$
\text { . } ڤ .
$$




\section{المركن القومي للبحوث التبويةوالتنمية}

العمادة مشرفون متخصصون لتوجيه تلك الأنشطة ومتابعة تتفيذها لتحقيق الأهداف العامة والخاصة للأنشطة الطلابية بالجامعة" وتضم الأنشطة الطلابية الأنشطة الثقافية، والاجتماعية، والرياضية، والجوالة، والمسرحية والتلفزيونية، وتتمية وتطوير

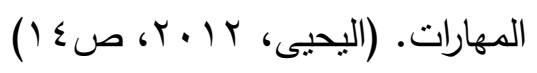

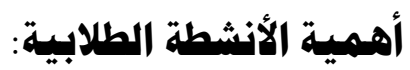

إن ما يميز الأنشطة الطلابية هو إقبال الطلاب نحوها عن رغبة ذاتية ودون إجبار من أحد وهذا يجعل من تلقي العلم والمعرفة من خلالها فائدة ومتعة أكبر من تلقيه عبر المناهج والكتب، خاصة حين تلبي هذه الأنشطة احتياجاتهم ورغباتهم المختلفة، وحين تكون متجددة بعيدة كل البعد عن الروتينية والتقليدية.

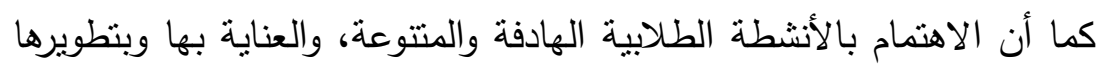
والتخطيط لها يعد وسيلة مثلى للمؤسسات التعليمية نحو تحقيق أهدافها وتحقيق

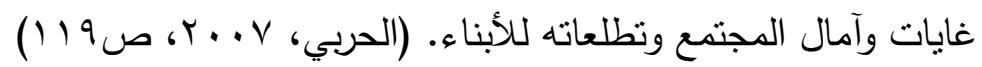
حيث تكسب الأنشطة الطلاب مقومات المواطنة الصحيحة من خلال تعريفهم بواجباتهم وحقوقهم ومسئولياتهم نحو المجتمع وتعمل على زيادة صلتهم ببيئتهم الاجتماعية وذلك من خلال مشاركتهم في الآراء والتعاون والعمل على اقتراح الحلول

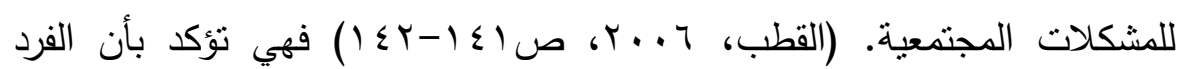
شخص منتمي لجماعة وأن هذه الجماعة بأثد الحاجة إليه وإلى مشاركته الفاعلة فيها.

كما أن الدوافع اللاشعورية أو المكبوتة لدى الفرد تخرج عن طريق ممارسة

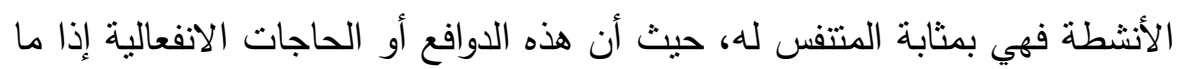
كبتت أو أخرجت بشكل غير منضبط فهي ستظهر على هيئة سلوكيات شاذة وغير 


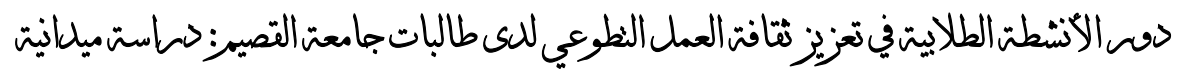

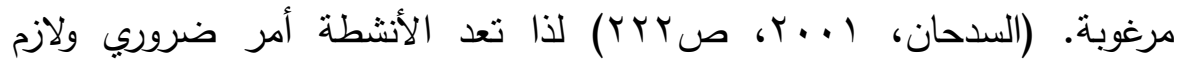
للطلاب كونها وسيلة ترويحية وتعليمية في الوقت نفسه. هعايير الأنشطة الطلابية:

تسعى الأنثطة الطلابية إلى تحقيق النمو الثنامل للطلاب من جميع جوانبهم المختلفة، ولكي يتحقق ذلك لابد من وضع عدد من المعايير والمنطلبات اللازمة عند التخطيط والبناء لهذه الأنشطة وبرامجها وذلك لضمان نجاحها وتحقيق الغرض

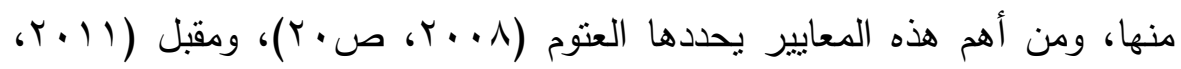

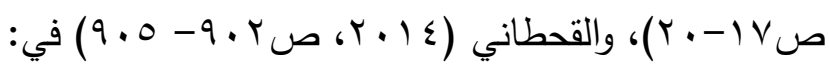
- معايير النشاط التي تتعلق بذات الأنشطة وطبيعتها:

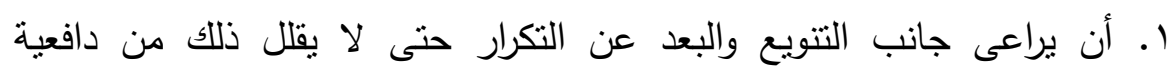

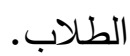

r. العمل على نوفير التجهيزات والاحتياجات والوسائل والأماكن الملائمة لكل نشاط.

r. عدم المبالغة سواء من ناحية الكم أو من ناحية الكيف في الأنشطة.

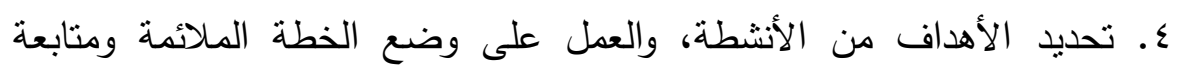

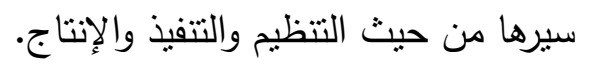

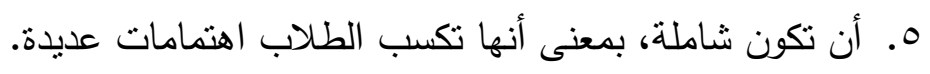

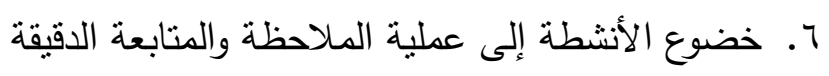

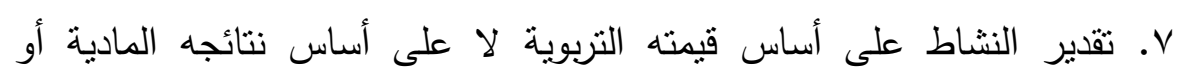

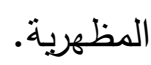
- معايير النشاط الني تتعلق بالطالب وميوله وقدراته: ا. أن تكون الأنشطة مناسبة لنمو الطلاب ومستواهم العمري ونضجهم العقلي. . รOY. البحث التربوي 


\section{المركن القومي للبحوث التبويةوالتنمية}

r. مراعاة الأنشطة الطلابية لقدرات واستعدادات الطلاب المختلفة وتوجيهها توجيهًا سليمًا.

r. أن تكون الأنشطة مربية، فتسهم في إكساب الطالب القيم والعادات الإيجابية. ع. أن تساهم في تحقيق النمو الشامل والمتكامل للطالب. - معايير النشاط التي تتعلق بالبيئة التي ينفذ بها النشاط:

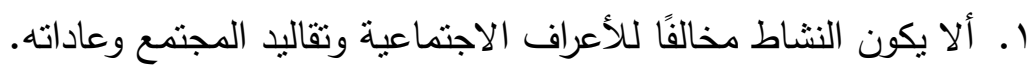

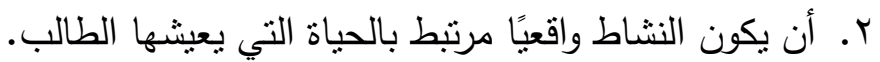
r. تحقيق التوازن والتوافق بين احتياجات نمو الفرد ومتطلبات المجتمع. ع. أن يشمل المعارف والمهارات والقيم اللازمة لحياة الطلاب في البيئة التي يعيشون بها. لذا لابد من اختيار المعايير التي تلائم ميولهم وقدراتهم مع مراعاة طبيعة الأنشطة والبيئة التي ينفذ بها النشاط، مما ينطلب تكتيف الجهود حول اختيار أنسب المعايير وأفضلها للطالب. ثقافة العهمل التطوحي: إن الحاجة إلى تطوع الأفراد بات أمرًا هامًا وضروريًا وحتى تكون هذه التقافة

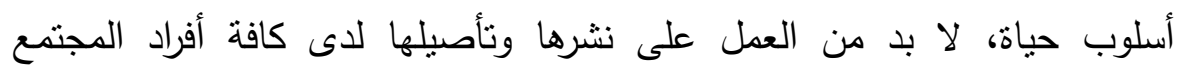
المختلفة مستلهمين كمجتمع مسلم ما لدينا من قيم ومبادئ تدعونا لسبل الخير

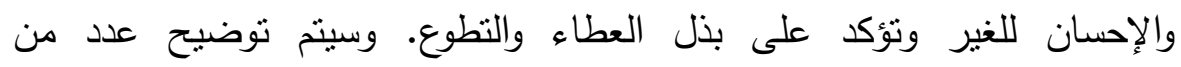
الموضوعات المتعلقة بثقافة العمل التطوعي منها: مقومات نقافة العمل التطوعي، أساليب ومعوقات تعزيز ثقافة العمل التطوعي، دور الأنشطة الطلابية في تعزيز

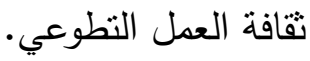




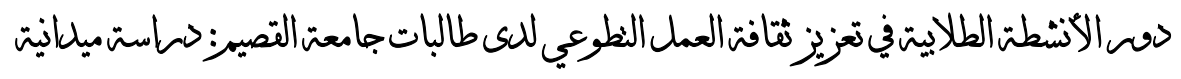

\section{هقوهات ثقافة العمل التطوعي:}

يعتمد العمل التطوعي على عدد من المقومات والعوامل التي نأخذ به نحو

النجاح والتميز وتتهض به، ولذلك من الأهمية معرفة أسباب النجاح وسبلها ليتم

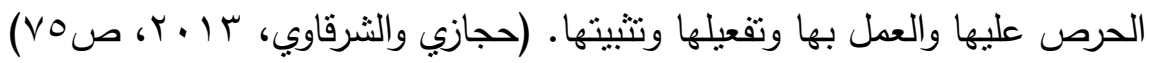
من ضمنها الاهتمام بنشر نقافة التطوع على الساحة الاجتماعية وتأصيلها لاى أفراد المجتم، وهذا لا يتم إلا من خلال امتلاك الأفراد للروئى والأفكار

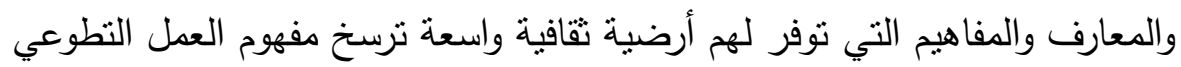

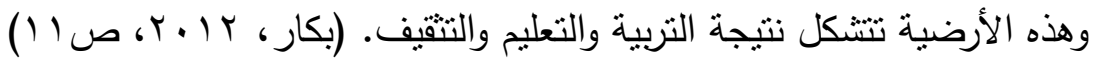
لذللك لا بد من إعادة صياغة خطاب النطوع بأسلوب مناسب ومعاصر يعمل على التأثير في الأجيال، ويركز على الفوائد والمكاسب العائدة على الأفراد المتطوعين كي يزداد مستوى وعيهم وقناعتهم بأهمية المشاركة في الأعمال التطوعية، بالإضافة إلى ترتيب الأولويات حسب ما يحتاجه المجتمع وما يطلبه.

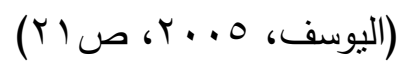

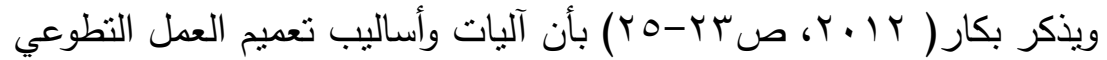

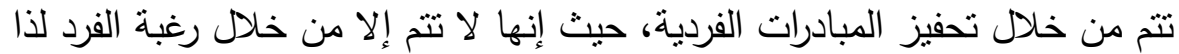

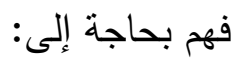

ا. بث روح التفاؤل لديهم فتحقيق النقدم والتتمية يظهر من خلال الممارسة والإسهام في الأنشطة النطوعية ولو كانت جهودًا بسيطة. r. حث الأفراد بأن يجربوا نوعًا من المتعة عند خدمة الآخرين فالعطاء والبذل سعادة عارمة تتتاب الفرد. 


\section{المركن القومي للبحوث التبويةوالتنمية}

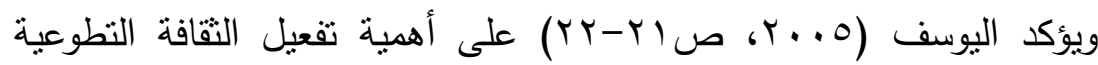
وتعزيزها على المستويين النظري التأصيلي والعملي التطبيقي في البنية الاجتماعية، ويذكر بأن ذلك يتم من خلال: 1. استقطاب عناصر جديدة لقيادة الأعمال التطوعية وذلك لخلق روح التجديد، والعمل على إنتاج الأفكار القوية والبرامج والأعمال الحديثة. r. تذليل الصعوبات والعقبات والمشاكل التي قد تعترض التطوع والمتطوعين، مع الأخذ بعين الاعنبار أهمية تشجيعهم ودعمهم معنويًا ليسهم ذلك في زيادة وصني عطائهم ونشاطهم. r. ان لا تقتصر الأعمال التطوعية على دعم الفقراء والمحتاجين فقط وإن كان ذلك من صلب الأعمال النطوعية، إلا أنه توجد قضايا أيضًا يجب النماء النظر

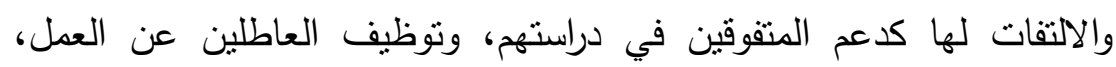
إضافة إلى دعم الإنتاج الفكري والثقافي.. إلخ.

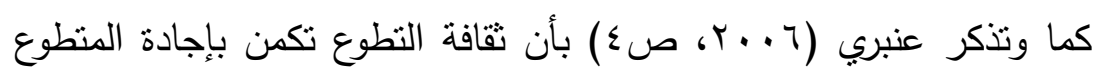
لهذه الأركان الأربعة وهي مهارات "التخطيط، والتظيم، والتدريب، والتقييم".

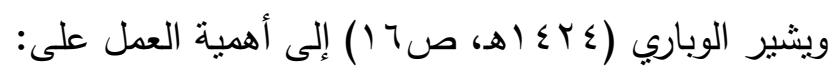

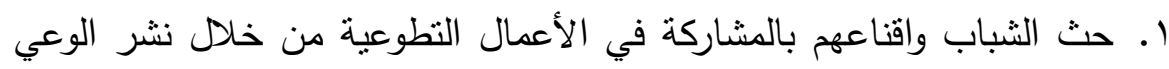
وترسيخه بينهم. r. مراعاة التخطيط على أسس علمية وإدارية مدروسة. r. تحديد احتياجات العمل التطوعي ومتطلباته. ع. الاهتمام بالنشء منذ الصغر وغرس حب التطوع في المراحل الدراسية الأولى. 0. توظيف وسائل الاتصال الحديثة كالإنترنت بالنتجيع على ممارسة التطوع. 


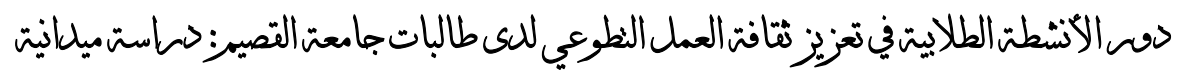

كما يلزم المؤسسات والمنظمات المستقبلة للأعمال التطوعية أن تتعامل مع

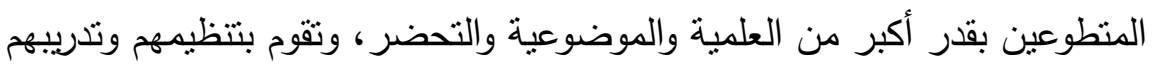

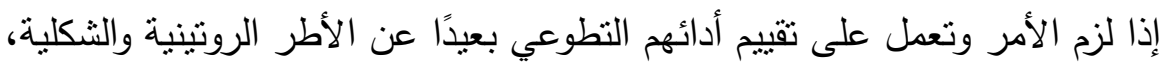

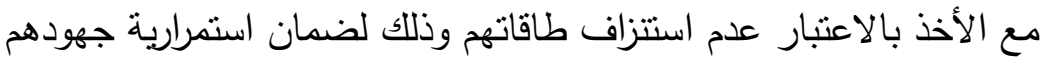

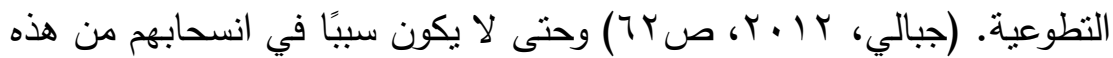
المؤسسة ونشاطاتها.

\section{أساليب تعزيز ثقافة العمل التطوعي:}

يحتاج المجتمع في مجال العمل النطوعي إلى انتشاره وتوسعه بين الناس

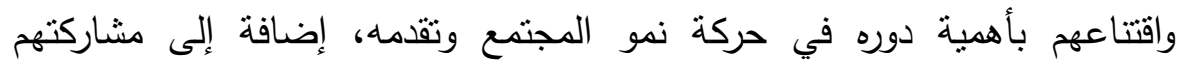
بمجالاته المختلفة ولتحقيق ذلك لا بد من إيمانهم بأن ذلك يعد جزء من واجباتهم ومسؤولياتهم الدينية والدجتمعية، وعلى الأسرة وكافة المؤسسات التعليمية والتربوية

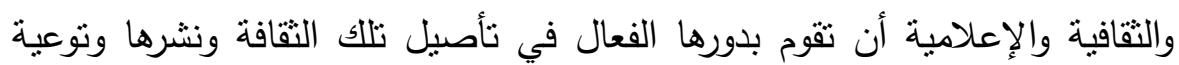

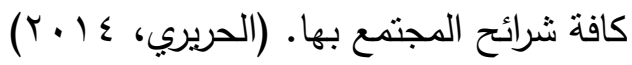

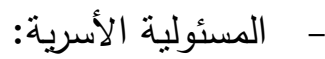

تعد الأسرة واحدة من وسائط التربية ذات الأهمية للفرد فهي تنعى جاهدة لتحقق احتياجات أبنائها وتقام الحماية والرعاية الكاملة لهم، حيث تهنم بتتشئتهم وتحصينهم من كل ما قد يؤثر على أفكارهم وسلوكياتهم سلبًا فيسئ لتربيتهم، فالأسرة المسلمة تعي مسئولياتها لذا تحرص كل الحرص على التربية السليمة لأبنائها من خلال غرس القيم وبناء الفضائل التي دعت إليها الثريعة الإسلامية. ويكتسب الفرد من خلال أسرته ومحيطه اللغة والعادات والقيم والتقافات والقدرة على إصدار الأحكام بالصواب والخطأ، كذلك أساليب إنثباع حاجاته ورغباته

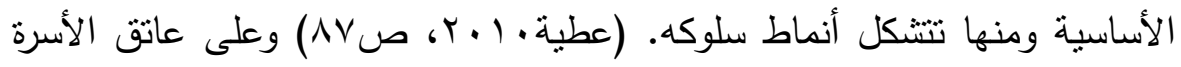




\section{المركن القومي للبحوث التبويةوالتنمية}

يقع جزء كبير من المسئولية في تربية أبنائها على تقديم الخدمات الاجتماعية، لذا لا بد أن تسهم بدورها في بناء ودعم المجتمع أمام أبنائها عن طريق المشاركة بتلك فئك الأعمال الخيرية، ليكتسب الأبناء تلك العادات فيتطبعون بها اقتداء بوالديهم فهم مثال يحتذى به، فالتربية بالقدوة تعتبر من الأساليب التربوية النافعة التي تحقق بلق

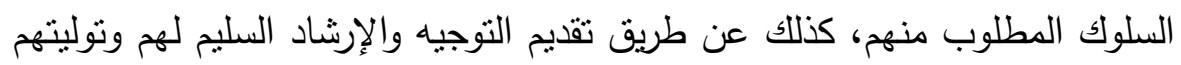
بعض المسئوليات التي تعزز من إحساسهم بالمسئولية المجتمعية، كل ذلك من شأنه

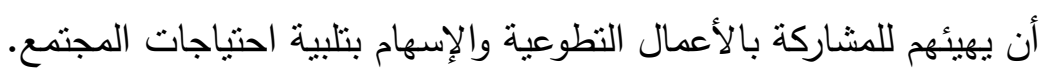

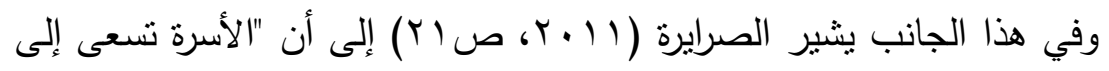
تتشئة أبناءها على الإحساس بالمسؤولية وتعزز قدرتهم على تحمل أعباءها، فتبدأ بتدريبهم على المبادرة في تحمل مسؤولياتهم تجاه أنفسهم بأنفسهم، فتبدأ بالأمور الصغيرة الهينة المحدودة ومن ثم تمضي إلى ما هو أكبر وأعقد وأصعب لتعد جيلاً قادرًا على تحمل المسؤولية". وبالتالي تعتبر الأسرة وسيلة هامة في بناء فكر يعي المسؤولية الاجتماعية ويحرص على تحقيق نمو المجتمع وتحضره. - - المسئولية التريوية التعليمية:

يعتبر التعليم بما يتضمنه من أنشطة ومناهج من الوسائل التي تكسب الطلاب الأخلاقيات الفاضلة، حيث يظهر دور المناهج التعليمية في توفير المواقف المربية التي ترمي إلى تشكيل قواعد السلوك الاجتماعية والأخلاقية لدى الطلاب. (زيادة،

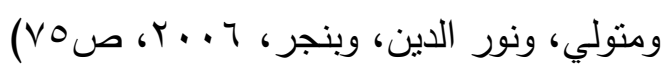

"فالمناهج التعليمية تلعب دورًا كبيرًا في تعزيز قيم وسلوكيات وأخلاقيات الطلاب والطالبات، ومن بين منظومة القيم والسلوكيات التي يمكن للتعليم أن يدعمها ثقافة العمل التطوعي، بما تحمله من تعاون وتكاتق ومحبة وانتماء وتفان

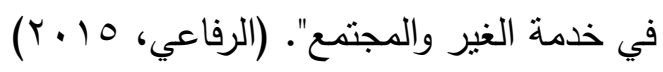




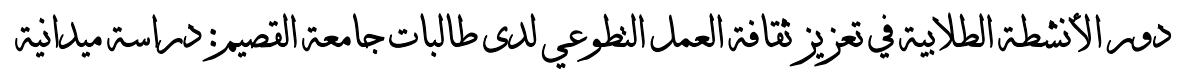

كما أن الأنشطة الطلابية لا تقل شأنًا عنها في ترويضهم على الثقافة التطوعية وغرس قيمها فيهم، فمن خلال تعويدهم على روح العمل الجماعي والتعاوني وبيان ما لذلك من آثنار إيجابية على الفرد والمجتمع، ينشأ لديهم إحساسًا بالمسؤولية وانتشارًا للفكر التطوعي ورغبة بالمشاركة فيه، وكل ذلك يتم من خلال

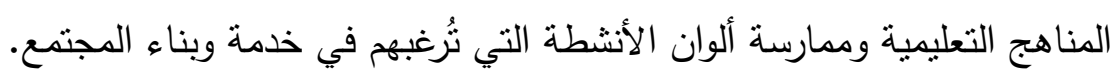
-

"يعد الإعلام في المجتمع أهم أجهزة الاتصال التي تؤدي دورًا مؤثرًا في تربية

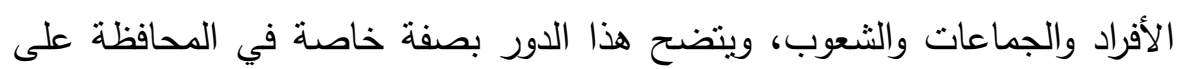
الهوية الثقافية للمجتمع من خلال المحافظة على قيمه وتراثه وتماسكه".(زبادة،

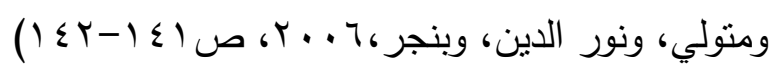

ووسائل الإعلام بأنواعها المقروءة والمسموعة والمرئية لها أثز بالغ في حياتتا

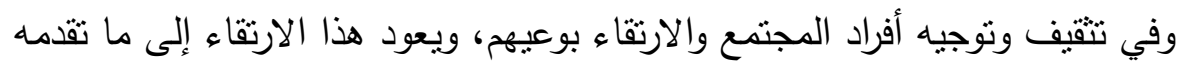

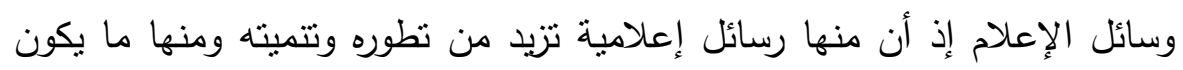

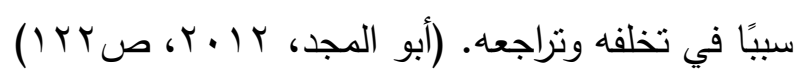

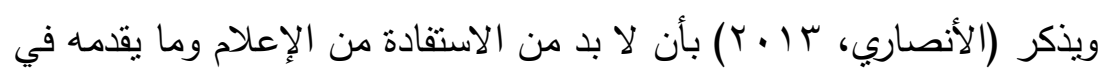

$$
\text { سبيل نتمية التقافة التطوعية وذللك عن طريق اتباع ما يلي: }
$$

ا ـ مساهمة وسائل الإعلام في تقديم الدورات التدربيية والندوات والمؤتمرات

العلمية التي تتعلق بالتطوع.

r. تتسيق الجهود بين أفراد المجتمع والمؤسسات الخيرية وإظهار ذلك عبر

الوسائل الإعلامية.

r. تأهيل الكوادر الإعلامية المدربة التي تتخصص في التطوع على اسس علمية وأكاديمية. 


\section{المركن القومي للبحوث التبويةوالتنمية}

ع. ـ إنشاء قاعدة بيانات لجميع المؤسسات التطوعية والخيرية بالمملكة. 0. إعداد البرامج التطوعية والقيام بالبث المباشر في كيفية معالجة الأزمات والكوارث.

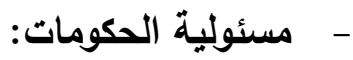

إن مسئولية انتشار ثقافة النطوع يقع جزء منها على عاتق الحكومات وأجهزتها، كونها تستطيع إنهاض هذه التقافة التطوعية من خلال وسائلها المتعددة، ويشير ياقوت (V) . . . V، صr؟) بأن على الحكومات أن تتبع استراتيجية معينة لتسهم في نشر الفكر التطوعي لاى أفراد المجتمع، حيث تشير هذه الاستراتيجية إلىى:

ا ـ إتاحة المشاركة التطوعية لجميع أفراد المجتمع والعمل على تطوير الخدمات التطوعية. r. التشجيع على التطوع وتسهيل الإجراءات في قيام الجمعيات والهيئات التطوعية وعدم تعقيدها.

r. تفعيل دور مراكز البحث العلمي بحيث تعمل على خدمة التطوع والتعرف تهف على سبل نشره.

ع. سن القوانين التي تلزم المواطنين بالتطوع بدلاً من دفع الغرامات المالية

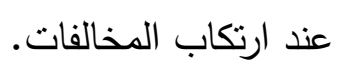
وتعد هذه الاستراتيجية مناسبة جدًا إذا طبقت على أرض الواقع، كونها تخدم التطوع وتوجد بيئة محفزة له.

\section{هموقات تعريز ثقافة العمل التطوعي:}

أصبحت المجتمعات الحديثة تحرص على تأصيل الثقافة التطوعية كونها أمر هام لتحقيق التتمية والرقي، إلا أن هناك بعض العوائق التي قد تحول دون تحقيق تحئ تحني .$\leqslant 09$. 


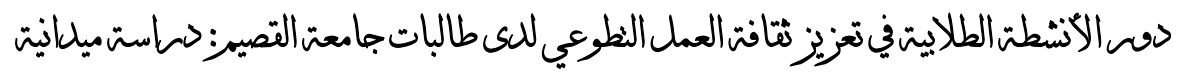

هذه الثقافة. وقد تتاول عدد من الباحثين هذه المعوقات منهم ياسين (1...r،

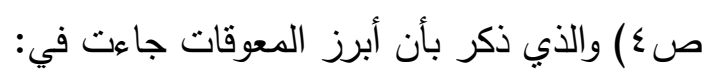

ا. ضعف في مستوى الوعي والإدراك لمفهوم وأهمية التطوع ومدى فائدنه

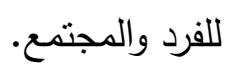

r. انتشار بعض الأفكار السلبية في المجتمع كالتقليل من شأن الششاركة

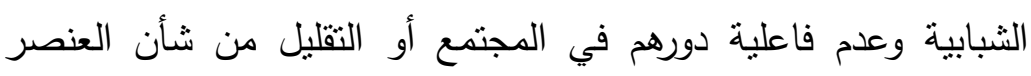

$$
\text { النسائي مقارنة بالرجال. }
$$

r. ضعف المؤسسات الحكومية والأهلية في نشر برامجها وأنشطتها وتعريف بالفالف

$$
\text { الأفراد بها. }
$$

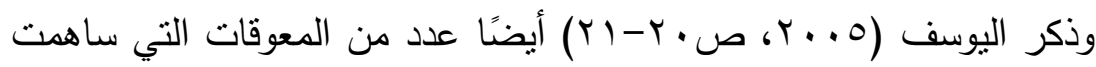

$$
\text { في تدني هذه الثقافة: }
$$

1. اهتمام الأفراد بشؤونهم الخاصة دون اكتراث بقضايا المجتمع ومصلحته

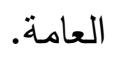

r. وجود بعض العوائق والمشاكل التي تعترض المتطوع وهذا يجعله يتجنب

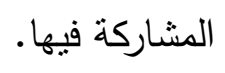

r. اختلاف الأولويات والاهتمامات حيث ينم التركيز على جوانب تقليدية

$$
\text { وإهمال جوانب مهمة تحتاج إلى النظر فيها. }
$$

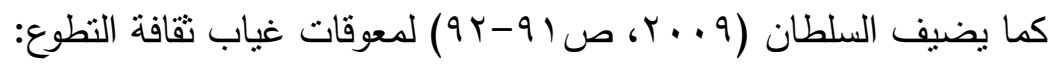

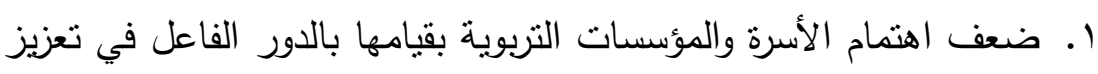

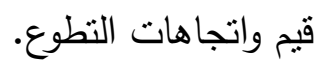




\section{المركن القومي للبحوث التبويةوالتنمية}

r. عدم تضمين المفاهيم التي تحث على التكافل والتعاون في المقررات والبرامج الدراسية، وهذا يعد من العوائق التي أدت إلى التقليل من شأن الأعمال التطوعية في نفوس الناشئة.

\section{دور الأنشطة الطلابية في تعريزز ثقافة العمل التطومي:}

تسهم الجامعات بدور فعال في التأثير على طلابها وطالباتها فهي تسعى لتكوين الجيل الذي يعمل على تغيير المجتمع وتحسين أوضاعه، راغبًا في تحقيق الرفعة والتتمية له ومراعيًا لمصالحه العامة، بالإضافة إلى بناء الثخصيات الخيرة والمعطاءة من خلال إرساء القيم وإكساب العادات الصحيحة وتعزيز المبادئ السائدة التي تتوافق مع المجتمع والالنزام بها، وذللك عن طريق وسائلها ومناهجها الدراسية وأنشطتها الطلابية المتعددة.

حيث تعد الأنشطة الطلابية ميدانًا خصبًا لتتمية الأخلاقيات والثقافات المطلوبة والإقبال على هذه الأنشطة يجعل من الطلاب أكثر قدرة على أداء أدوارهم

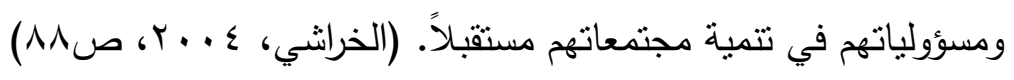

ويظهر دور النشاط الطلابي في تربية الطالب وتتمية ثقافته على التطوع من

خلال التركيز على الجانب المعرفي للتطوع وذللك ببث الأفكار والمعارف والمفاهيم المتعلقة، ثم الاهنمام بغرس الجانب القيمي عن طريق بناء القيم والمبادئ والاتجاهات التي تعزز من قيم التطوع لديهم، والتركيز أيضًا على الجانب التطبيقي وهو الأهم والذي يشتمل على الممارسة والوسائل العملية للتطوع على أرض الواقع،

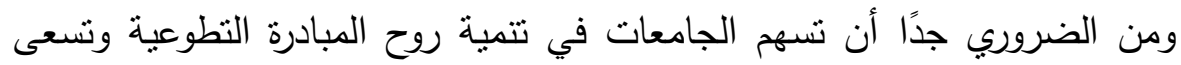
لإيجاد ثقافته وذللك من خلال إنشاء ناد طلابي تطوعي يشجع ويرغب على العطاء وبهنم في كافة الأنشطة التطوعية وفعالياتها، حيث يعمل على جذب الطلاب للمشاركة الفعالة من خلال إعداده للبرامج الملائمة والمتجددة كتكوين فرق تطوعية 


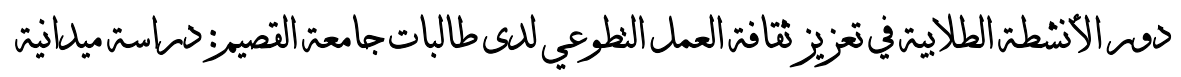

تتخصص في المجالات التي يرغبها الطلاب وذللك مراعاة لنوجهاتهم وميولهم

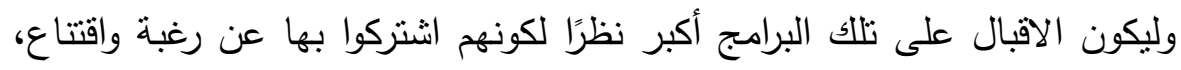
فالطالب حينما يجبر على مجال أو نشاط لا يرغبه فإن فاعليته وجهده يقلان فيه، كنلك يمكن للوحدة إدراج أنشطة خارج الجامعة تهنم في التعريف بمؤسسات

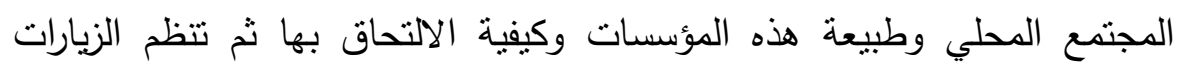

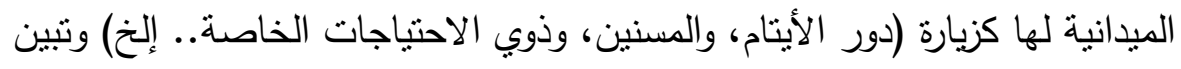
مدى حاجة هذه الفئات لهم كمنطوعين وأهمية الإحسان بهم، لا بد أيضًا من إقامة الأنة

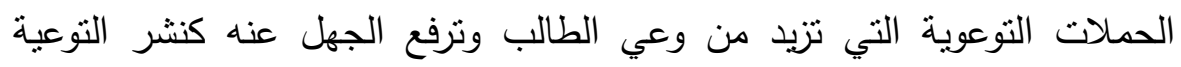

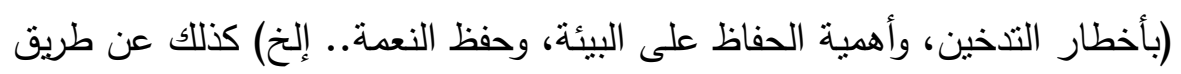

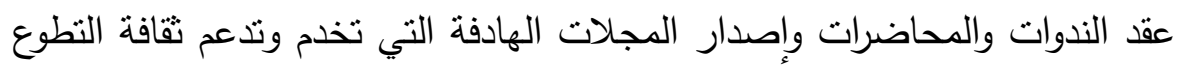

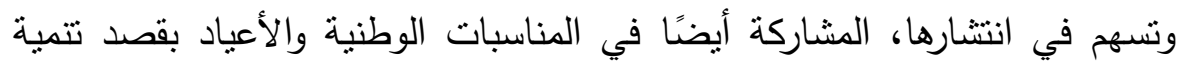

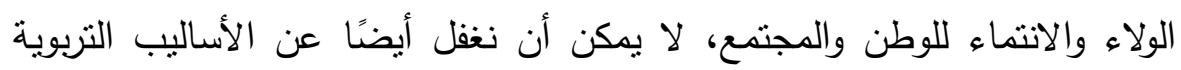

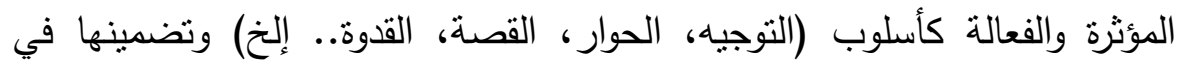

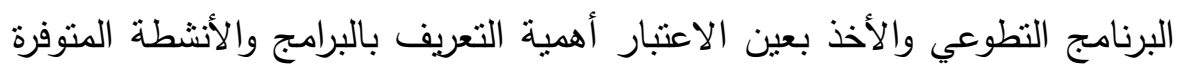

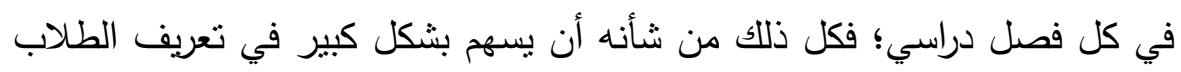
بالتطوع ومجالاته، وتربية شخصيته وفكره على الإحسان والرغبة في العطاء

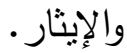

ويمكن القول بأن غرس ثقافة التطوع تتم بتحفيز المبادرة الذاتبة لديهم، فأداءهم

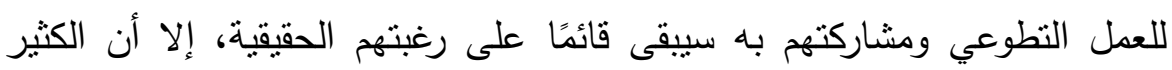
منهم يغفلون عن دورهم في خدمة مجتمعاتهم، لذا فهم بحاجة إلى بلورة الأفكار

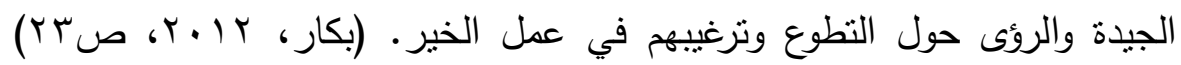
وإناحة الفرصة لهم بممارسته داخل الجامعة وخارجها. 


\section{المركن القومي للبحوث التبويةوالتنمية}

وعلى وحدة الأنشطة أن نراعي الطلاب من خلال تخصيصها لعدد من

الساعات الأسبوعية يمارس الطالب فيها حقه بالتطوع دون أي تعارض مع محاضراته وجدوله الدراسي ومراعاة ذللك عند رسم وإعداد الأنشطة والبرامج النطوعية، ولا بد من الإثارة أيضًا إلى أهمية مبادرة الطلاب والطالبات في طرح أفكارهم حول برامج وأنواع الأنشطة التطوعية التي يرغبونها ثم صياغتها والتخطيط لها ليتم بعد ذلك إعدادها وتتفيذها لهم.

ومن الضروري أيضًا أن تتتوع الأنشطة كمًا وكيفًا لتسهم في إعداد الفرد وتتمي لديه الجوانب الثخصية وتكون لنا المواطن المدرك لحقوقه وواجباته تجاه

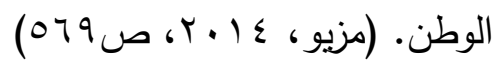
وتتشير الكثير من الدراسات على قدرة الأنشطة وأثرها الفعال في تتمية جوانب

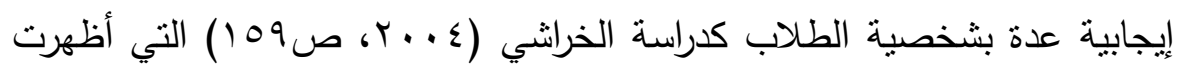
بأن الأنثطة الطلابية لها تأثثر كبير في عملية إكساب وتتمية المسئولية الاجتماعية للطلاب، وأن هناك وعي كبير بها بالنسبة لممارسي الأنشطة الجامعية.

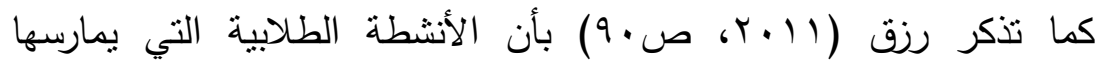
الطلاب في الجامعة تسهم بدرجة كبيرة في تتمية قيم الانتماء العقدي والسياسي والاجتماعي والبيئي. وهذا يؤكد قدرتها في التأثير على الطلاب، لما أثنار الباحثون له من حيث أهميتها في تحقيق التكامل لنواحي عديدة لدى الطلاب وذلك بتتمية قدراتهم، وزيادة تفوقهم، وبناء ثقافاتهم، واستثمار وقتهم، وهذا كله يؤكد أن الأنشطة باستطاعتها تفعيل ثقافة كثقافة العمل التطوعي وتعزيزها لديهر من خلال بث الأفكار التي تدعو إلى ممارسة الأعمال الخيرية والتطوعية، وتهيئة المناخ الملائم الذي يكسبهم تلك مئك 


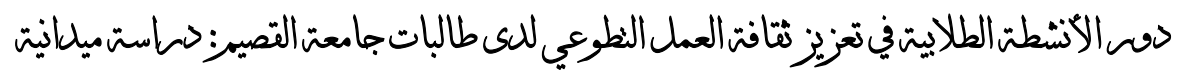

النقافة لتكون جزءًا من سلوكياتهم اليومية وعادة تلازمهم حتى بعد تخرجهم

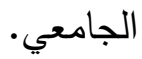

ثالثا: الدراسة الميدانية ونتائجها:

هنهج الدراسة:

المنهج الوصفي وهو المنهج المناسب لمثل هذه الدراسات حيث يقوم على الدي

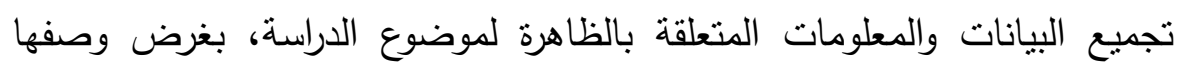

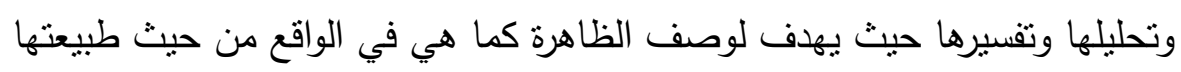

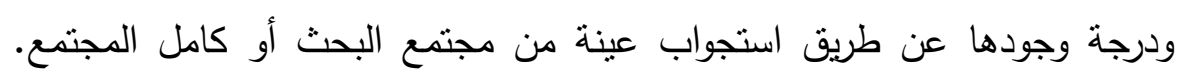

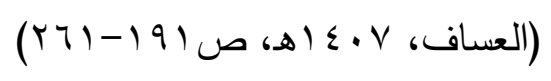

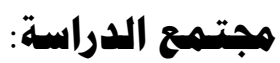

يمثل المجتمع في الدراسة الحالية جميع الطالبات المنتظمات بجامعة القصيم

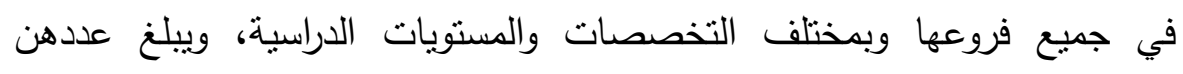

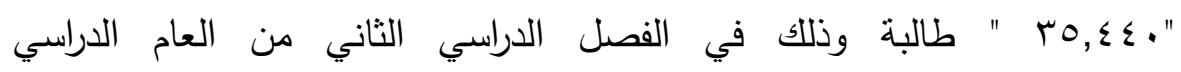

$$
\text { عينة الدراسة استه: اله. }
$$

اعتمدت الدراسة على أسلوب اختبار عينة بطريقة عشوائية طبقية من طالبات جامعة القصيم من كليات (الثريعة والدراسات الإسلامية، التربية، العلوم والآداب، التصاميم والاقتصاد المنزلي، الصيدلة) من جميع المستويات الدراسية في الفصل

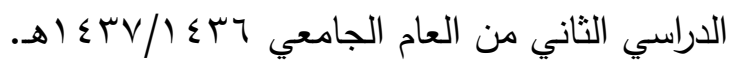
تم التأكد من صدق وثبات الاستبانة المستخدمة في الدراسة الحالية بالتطبيق الإنيق عليها من (Av) طالبة اعتمد أسلوب اختيارهن بطريقة عشوائية. . $\leqslant า \varepsilon$. البحث التربوي 


\section{المركن القومي للبحوث التبويةوالتنمية}

- عينة الدراسة الأساسية: تكونت عينة الدراسة الأساسية من (Y +ع) طالبة من طالبات جامعة القصيم اختيرت بطريقة عشوائية طبقية من طالبات كليات (الثربعة والدراسات الإسلامية، التربية، العلوم والآداب، التصاميم والاقتصاد المنزلي، الصيدلة) من جميع المستويات الدراسية في الفصل

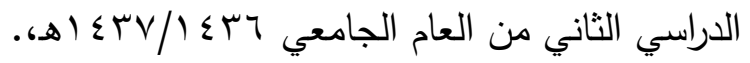

\section{أداة الدراسة:}

استخدت الاستبانة كأداة لجمع البيانات، وتضمنت بصورتها النهائية

محورين، شملت بداية على البيانات الأولية للعينة. ثم المحور الأول: والذي يتعلق بواقع دور الأنشطة الطلابية في تعزيز ثقافة العمل التطوعي، ويشتمل على ثلاثة أبعاد: الجانب المعرفي، الجانب القيمي، الجانب التطبيقي.

المحور الثاني: ويتعلق بالمعوقات التي تحول دون تحقيق الأنشطة الطلابية لدورها في تعزيز ثقافة العمل التطوعي ويشتمل المحور الثاني على ثلاثة أبعاد: المعوقات المرتبطة (بالجامعة، والطالبة، والمجتمع) وتضمنت الاستبانة بصورتها

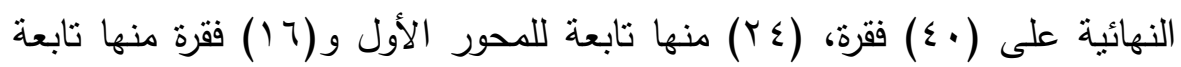
للمحور الثاني.

وتتم الاستجابة لعبارات الاستبانة بأن تختار الطالبة من بين ثلاثة اختيارات هي (نعم، إلى حد ما، لا) لتقابل الدرجات (ץ، ب، ( ) على الترتيب؛ والدرجة المرتفعة تعبر عن درجة عالية لدور الأنشطة الطلابية في تعزيز ثقافة العمل النظوعي لاى طالبات جامعة القصيم، وكذلك بالنسبة للمحور الثاني للاستبانة تعبر الدرجة المرتفعة عن أن المعوق يتحقق بدرجة كبيرة، ويجب ملاحظة أنه تم الاعتماد على المحكات التالية في تحديد دور ومعوقات الأنشطة الطلابية في تعزيز ثقافة 
دص الأنشطتا الطلايتش في تعزيز ثثافت الممل النطوعي للى طالبات جامعت التصيي:دماستميلانيت

العمل التطوعي لدى طالبات جامعة القصيم، بناءً على المتوسطات الحسابية للعبارات والمتوسطات الموزونة للمحاور :

جدول رقم (1)

محكات الحكم على واقع دور ومعوقات الأنشطة الطلابية في تعزيز ثقافة العمل التطوعي لاى طالبات جامعة القصيم.

\begin{tabular}{|c|c|}
\hline درجة التحقق & المتوسط الحسابي للعبارة أو المتوسط الموزون \\
\hline ضعيفة أو منعدمة & أقل من Vד T, 1 \\
\hline منوسطة & من Vד T, 1 لأقل من ع سז,ץ \\
\hline 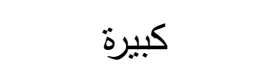 & من ع سب,r فأكثز \\
\hline
\end{tabular}

صدق وثبات الاستبانة:

الصدق الظاهري: عرضت الاستبانة في صورتها الأولية على مجموعة من

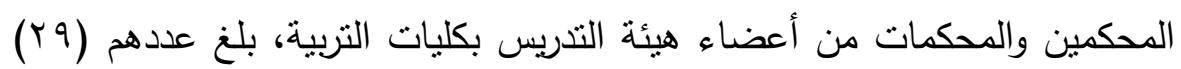
محكمًا بالتخصصات التالية (أصول تربية- إدارة تربوبة- علم نفس - مناهج وطرق

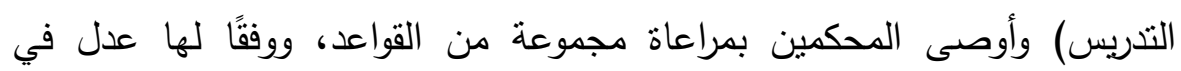
صياغة بعض العبارات وترتيبها أو حذفها. صدق الاتساق الداخلي: تم كذلك التحقق من صدق الاستبانة عن طريق صدق الاتساق الداخلي وذللك بحساب معامل الارتباط بين درجة كل عبارة مع الدرجة الكلية للجانب المنتمية إليه العبارة بعد حذف درجة العبارة من الدرجة الكلية

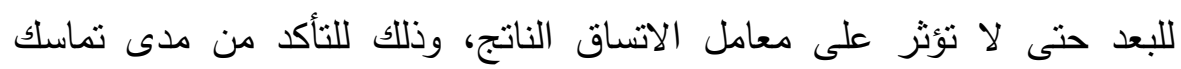
وتجانس عبارات كل بعد فيما بينها، فكانت معاملات الارتباط بين درجات عبارات 


\section{المركن القومي للبحوث التبويةوالتنمية}

أبعاد الاستبانة والدرجة الكلية للبعد المنتمية إليه العبارة بعد حذف درجة العبارة من درجة البعد معاملات ارتباط موجبة ودالة إحصائيًا عند مستوى ا +, , وهو ما يؤكد اتساق وتجانس عبارات كل بعد فيما بينها. كذلك تم التأكد من تجانس واتساق الجوانب المختلفة لدور الأنشطة الطلابية في تعزيز ثقافة العمل التطوعي لدى طالبات جامعة القصيم ومعوقات ذلك الدور، فكانت معاملات الارتباط موجبة ودالة إحصائيًا عند مستوى 1 .,. . وهو ما يؤكد اتساق وتجانس الجوانب المختلفة لدور الأنشطة الطلابية في تعزيز ثقافة العمل التطوعي لدى طالبات جامعة القصيم فيما بينها، وكذللك اتساق وتجانس الجوانب المختلفة للمعوقات فيما بينها. الثبات: تم التحقق من ثبات درجات الأبعاد المختلفة للاستبانة الحالية باستخدام معامل ثبات ألفا كرونباخ فكانت معاملات الثبات جيدة ومقبولة إحصائيًا.

\section{عرض وتهليل نتائج الدراسة الميدانية:} نتائج الإجابة على السؤال الأول ومناقتشها: ينص السؤال الأول للدراسة الحالية على "ما واقع دور الأنشطة الطلابية

بجامعة القصيم في تعزيز ثقافة العمل التطوعي لدى طالبات الجامعة؟ وللإجابة عن هذا السؤال قسم الدور إلى ثلاث جوانب وهي الجانب (المعرفي والقيمي والتطبيقي) وسيتم دراسة كل جانب من هذه الجوانب على حدة: 1- الجانب المعرفي: المعلومات والمعارف المتعلقة بالعمل التطوعي: 


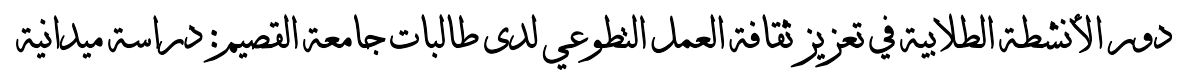

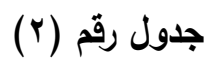

المتوسطات الحسابية والانحرافات المعيارية لاستجابات عينة الدراسة حول واقع دور الأنثطة الطلابية في تعزيز ثقافة العمل التطوعي لاى طالبات الجامعة والمتعلقة

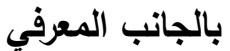

\begin{tabular}{|c|c|c|c|c|c|}
\hline الترتيب & التحقق & الانحراف & المتوسط & العبارات & 5 \\
\hline$\wedge$ & متوسطة & $\cdot, V T V$ & $r, \cdot \wedge V$ & التعريف بالبرامج التطوعية المتاحة في كل & 1 \\
\hline 0 & متوسطة & $\cdot, V T r$ & $r, 19 \varepsilon$ & خعزيز الوعي بأهمية المشاركة المجتمعية من تقديم المحاضرات والندوات الفاعلة & $r$ \\
\hline 7 & متوسطة & •, VAr & $r, 10 r$ & $\begin{array}{c}\text { توضيح اللوائح التي تتظم العمل التطوعي } \\
\text { وتحمي المتطوعين }\end{array}$ & $r$ \\
\hline$\varepsilon$ & متوسطة & $\cdot, \vee \vee \neg \leq$ & $r, r q q$ & الطالبات بالعمل التطوعي ودورهن فئل التواصل الاجتماعي لتعريف المجتمع & $\varepsilon$ \\
\hline 1 & كبيرة & $\cdot, V \cdot T$ & $r, \Sigma 00$ & تثقيف الطالبات بأهمية المحافظة على النظافة & 0 \\
\hline r & كبيرة & $\cdot, V Y \leq$ & r.r. & الطتثمار الأيام التوعوية في المجتمع لتنقيف & 7 \\
\hline r & متوسطة & $\cdot, \vee>7$ & וזr,r & 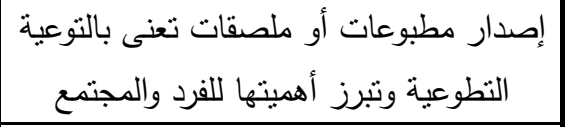 & $V$ \\
\hline V & متوسطة & $\cdot, v q r$ & $r, 1 \cdot \varepsilon$ & إقامة مسابقات وبحوث نتناول قضايا التطوع & $\wedge$ \\
\hline \multicolumn{2}{|c|}{ متوسطة } & $\cdot, 011$ & $r, r \leq q$ & \multicolumn{2}{|c|}{ ور الأنشطة الطلابية في تعزيز ثقافة العمل التطوعي } \\
\hline
\end{tabular}

$. \leqslant\urcorner \wedge$. 


\section{المركن القومي للبحوث التبويةوالتنمية}

يتضح من الجدول السابق أن هناك عبارات تحققت بدرجة كبيرة في

الجانب المعرفي كعبارة "تثقيف الطالبات بأهمية المحافظة على النظافة العامة داخل مرافق الجامعة" وتفسر هذه النتيجة بأن وحدة الأنشطة الطلابية في الجامعة تبادر في توعية الطالبات بأهمية المحافظة على الأماكن العامة وتثقيفهن بضرورة تحقيق النظافة في مرافق الجامعة والحفاظ على البيئة المحيطة بهن، مما يساهم في زيادة مستوى الوعي لديهن والإحساس بالمسؤولية نحو البيئة "فهناك رابط قوي ومتين ما بين حماية البيئة والعمل التطوعي من منطلق أن البيئة وحمايتها شأن يهم الجميع وعلى تماس مباشر مع مختلف فئات المجتمع، وحماية البيئة أيضًا واجب وطني مُني وضرورة محلية وإقليمية وعالمية" (العمل التطوعي البيئي، • 1 • ب) وتتفق النتيجة إلى

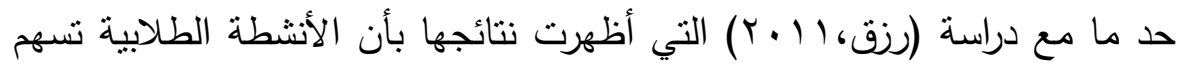
في تتجيع الطلاب نحو الحفاظ على نظافة البيئة وحسن التعامل معها، كما جاءت أقل العبارات تحققًا في الجانب المعرفي "التعريف بالبرامج التطوعية المتاحة في كل فصل دراسي" وتتشير هذه العباره بهذا الترتيب إلى وجود ضعف بوحدة النشاط في الإعلان و التعريف بالبرامج التطوعية المعدة وهذه مشكلة تواجه تفعيل العمل التطوعي في الجامعة إذ لا بد من التركيز على نشر برامجه والتعريف بها. r- الجانب القيمي: القيم والمعتقدات المرتبطة بالعمل التطوعي: 


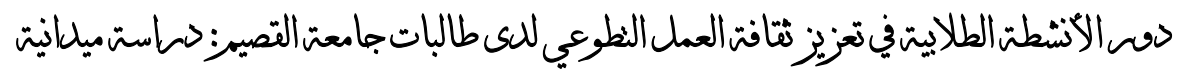

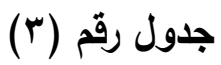

المتوسطات الحسابية والانحرافات المعيارية لاستجابات عينة الدراسة حول واقع دور

الأنثطة الطلابية في تعزيز ثقافة العمل التطوعي لاى طالبات الجامعة والمتعلقة بالجانب القيمي

\begin{tabular}{|c|c|c|c|c|c|}
\hline الترتيب & دالتحقق & الانحراف & المتوسط & 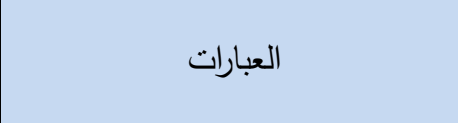 & مم | مح \\
\hline 7 & متوسطة & $\cdot, \mathrm{V} \cdot \Lambda$ & $r, Y q 1$ & 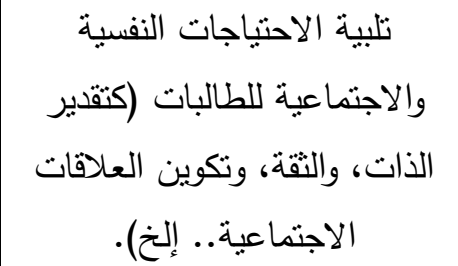 & 11 \\
\hline$r$ & كبيرة & $\cdot, 7 \vee V$ & r,r & المجتمع والتفاعل مع احتباجاته المسؤلية تجاه & ir \\
\hline 1 & كبيرة & $\cdot, 7 Y \leqslant$ & Y,OVO & وموريخ قيم الدين الإسلامي المجتمع القائم على التىافل الاجتماعي. & 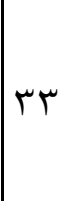 \\
\hline$\varepsilon$ & كبيرة & $\cdot, \vee \backslash \backslash \leq$ & $r, r \leq 1$ & تعميق روح المواطنة وترسيخ & $\Sigma \varepsilon$ \\
\hline 0 & متوسطة & $\cdot, V \cdot V$ & T, Tr & تشجيع الطالبات على الالتزام & 00 \\
\hline v & متوسطة & $\cdot, V \leq 0$ & $r, r \cdot q$ & تتمية قيم التضحية والإيثار لدى & 77 \\
\hline
\end{tabular}

.$\leqslant \vee \cdot$.

البـحث التتربوي 


\section{المركن القومي للبحوث التبويةوالتنمية}

\begin{tabular}{|c|c|c|c|c|c|}
\hline الترتيب & التحققة & الانحراف & المتوسط & العبارات & مح \\
\hline & & & & الطالبات. & \\
\hline r & كبيرة & $\cdot, V \cdot r$ & $r, \leqslant 10$ & تعزبز قيمة التعاون عند ممارسة & VV \\
\hline \multicolumn{2}{|c|}{ كبيرة } & $\cdot, 010$ & r, & \multicolumn{2}{|c|}{ دور الأنشطة الطلابية في تعزيز ثقافة } \\
\hline
\end{tabular}

يتضح من الجدول السابق أن هناك عبارات تحققت بدرجة كبيرة في

الجانب القيمي كعبارة "ترسيخ قيم الدين الإسلامي وموروث المجتمع القائم على التكافل الاجتماعي" وعبارة "تعزيز قيمة التعاون عند ممارسة الطالبات لمهامهن التطوعية" كذلك عبارة "تتمية روح المسؤولية تجاه المجتمع والتفاعل مع احتياجاته المختلفة" وعبارة "تعميق روح المواطنة وترسيخ قيمها من خلال المشاركة في المناسبات الوطنية" وتفسر هذه النتيجة باهتمام المسؤولين في الجامعة وحرصهم على ترسيخ القيم الإيجابية النابعة من تعاليم الدين الإسلامي واهتمامهم بتتميتها لاى الناشئة وذللك لإيمانهم بأن القيم هي من تشكل شخصية الفرد وتحفظ فكره وتحدد سلوكه، فالمؤسسات التربوية ككل بمسؤوليها ومناهجها وأنشطتها وبرامجها تهدف إلى غرس القيم الإيجابية المتتوعة (كالتكافل، والتعاون، تنمية الإحساس بالمسؤولية.. إلخ) واكتساب مثل هذه القيم يزيد من الوعي نحو الثقافة التطوعية ويعززها. وتتفق هذه النتيجة إلى حد ما مع دراسة (الموسي، 17 • ب) التي أوضحت

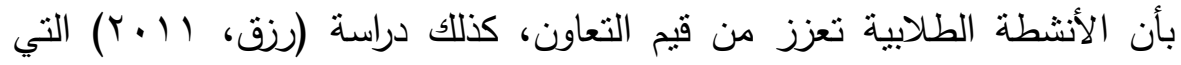

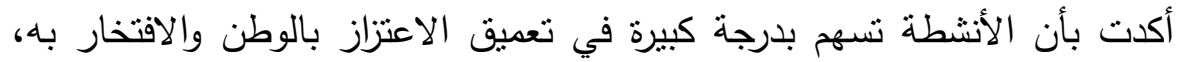




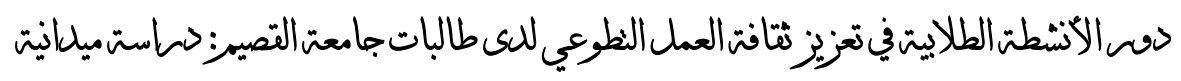

ودراسة (حسين، 0. . ب) التي أكدت على الدور الإيجابي للأنشطة الطلابية في

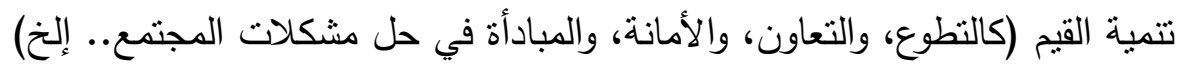

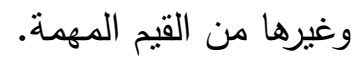

r- الجانب النطبيقي: الممارسة الفعلية المرتبطة بالعمل التطوعي:

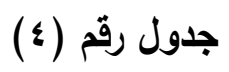

المتوسطات الحسابية والانحرافات المعيارية لاستجابات عينة الدارسة حول واقع دور الأنثطة

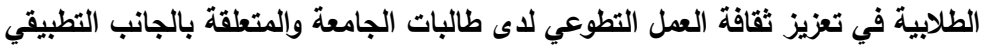

\begin{tabular}{|c|c|c|c|c|c|}
\hline |الترتيب|| & | التحقق & المعياري & | المتوسط | & العبارات & 5 \\
\hline 0 & | متوسطة | & $\cdot, \vee \vee \wedge \vee$ & $Y, Y \backslash Y$ & | لعروة المختصين بالأعمال التطوعية & 1 \\
\hline 9 & | متوسطة | & $\cdot, \lambda \cdot V$ & $Y, I Y Y$ & تلظيم زيارات ميدانية لمؤسسات المتمع المحلي والتعرف على احتياجاتها التطوعية. & r \\
\hline r & | متوسطة | & $\cdot, V \Gamma \varepsilon$ & Y,YTE & تبني أفكار الطالبات النطوعية & $r$ \\
\hline 1 & كبيرة & •,709 & r,OYV & كشروع (حفظ النعمة، التبرع بالدم.. & $\varepsilon$ \\
\hline r & | متوسطة & $\cdot, \wedge)$ & r, rrq & تقديم العون للأسر الفقبرة من خلال & \\
\hline
\end{tabular}




\section{المركن القومي للبحوث التبويةوالتنمية}

\begin{tabular}{|c|c|c|c|c|c|}
\hline الترتيب| & |التحقق & الانحراف & المتوسط & العبارات & 5 \\
\hline & & & & $\begin{array}{c}\text { حملات التبرع (بالملابس، } \\
\text { والأثاث،.. إلخ). }\end{array}$ & 0 \\
\hline V & متوسطة & $\cdot, \vee \vee \uparrow$ & $r, 1 \wedge \varepsilon$ & بهافة التبرع حفلات ومعارض مختلفة & 7 \\
\hline$\varepsilon$ & متوسطة & $\cdot, \vee \vee \vee$ & $r, Y M)$ & تدريب الطالبات على الأعمال & V \\
\hline 7 & متوسطة & $\cdot, V T V$ & $r, 199$ & للاشتراك في الأعمال التطوعي الفرص المتاحة. & $\wedge$ \\
\hline$\wedge$ & متوسطة & $\cdot, \Lambda \cdot r$ & $r, 17 r$ & الأنشاحة الوقت الكافي لممارسة & 9 \\
\hline طة & متوس & $\cdot, 007$ & $r, Y \mu \wedge$ & \multicolumn{2}{|l|}{ دالعمل النطوعي لأنشطة الطلابية في تعزيز ثقافة } \\
\hline
\end{tabular}

يتضح من الجدول السابق أن هناك عبارة تحققت بدرجة كبيرة في الجانب التطبيقي وهي "إقامة حملات تطوعية خلال العام كمشروع (حفظ النعمة، التبرع بالدم.. إلخ)" ويفسر ذلك بأن وحدة الأنشطة في الجامعة نولي اهتمامًا كبير بتفعيل الحملات والتي تعتبر تجربة وخبرة جيدة للطالبة في ممارسة العمل التطوعي حيث 


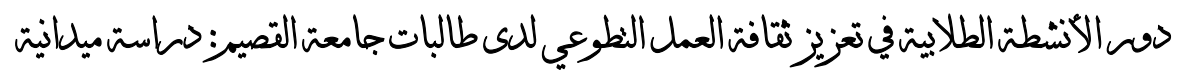

تسهم في تثقيفها نحوه. وجاءت أقل العبارات تحققًا "تتظيم زيارات ميدانية لمؤسسات المجتمع المحلي والتعرف على احتياجاتها التطوعية" وتفسر هذه النتيجة بوجود قصور في تفعيل مثل هذه الزيارات التي لها أثز فعال وكبير في تعزيز التقافة التطوعية والمعايثة الحقيقية للطالبة لمدى حاجة هذه المؤسسات لهن كمتطوعات. نتائج الإجابة على السؤال الثاني ومناقثتها: ينص السؤال الثاني للدراسة الحالية على "ما المعوقات التي تحول دون تحقيق الأنشطة الطلابية في جامعة القصيم لدورها في تعزيز ثقافة العمل التطوعي

$$
\text { لدى طالبات الجامعة؟ الاسن }
$$

قسمت المعوقات لثنلاث جوانب وهي المعوقات المرتبطة (بالجامعة،

والطالبة، والمجتمع) وسيتم دراسة كل معوق من هذه المعوقات على حدة:

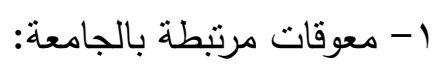

\section{جدول رقم (0)}

المتوسطات الحسابية والانحرافات المعيارية لاستجابات عينة الدراسة حول المعوقات المرتبطة

\begin{tabular}{|c|c|c|c|c|c|}
\hline 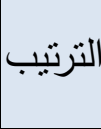 & التحقق & الالمعراف & المتوسط & 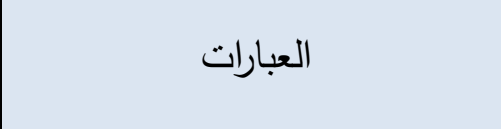 & 5 \\
\hline$\varepsilon$ & متوسطة & $\cdot$, , Y O & $r, Y \wedge q$ & ضعف التعريف بالأنشطة التطوعية & 1 \\
\hline$r$ & متوسطة & $\cdot, V Y Y$ & r, & بالأنشطة التطوعية داخل المقرر الدراسي & r \\
\hline r & 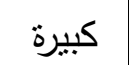 & $\cdot, \vee Y Y$ & צדוז,r & تركيز أعضاء هيئة التدريس على & r \\
\hline
\end{tabular}

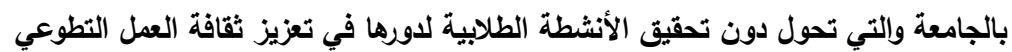




\section{المركن القومي للبحوث التبويةوالتنمية}

\begin{tabular}{|c|c|c|c|c|c|}
\hline الترتيب & درجة & الانحراف & المتوسط & العبارات & r \\
\hline & & & & المقررات الدراسية وإهمال الأنشطة & \\
\hline 1 & كبيرة & $\cdot, 79 \leq$ & $r, \leq \leqslant \Lambda$ & ضلالتحاق الحوافز المعنوبة المشجعة & $\varepsilon$ \\
\hline 0 & متوسطة & • & $r, r \circ 7$ & قلة وجود نشرات ودوريات تثقيفية & 0 \\
\hline \multicolumn{2}{|c|}{ كبيرة } & $\cdot, 01 Y$ & סץץ, & \multicolumn{2}{|c|}{ تحقيق الأنشطة الطعات المرتبطة بالجامعة والتي تحول دون لدورها في تعزيز } \\
\hline
\end{tabular}

بتضح من الجدول السابق أن هناك عبارات تحققت بدرجة كبيرة في المعوقات المرتبطة بالجامعة وهي "ضعف الحوافز المعنوية المشجعة للالتحاق بالأنشطة التطوعية" وعبارة "تركيز أعضاء هيئة التدريس على المقررات الدراسية

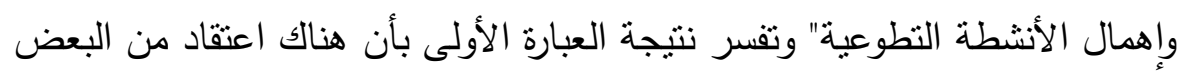

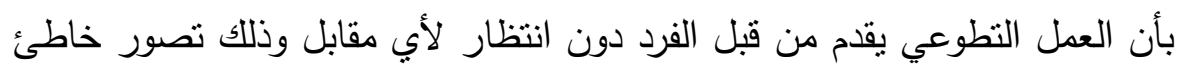
فالفرد بحاجة إلى تعزيز وثثاء على ما يبذله من جهود حتى لا يعرضه ذلك إلى الإحباط والثعور بعدم التقدير وتتفق هذه النتيجة إلى حد ما مع دراسة كل من

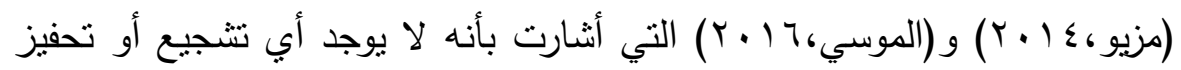

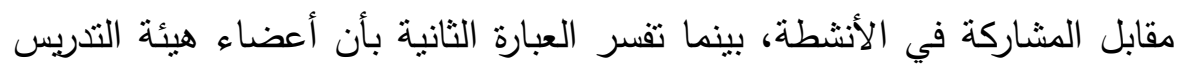

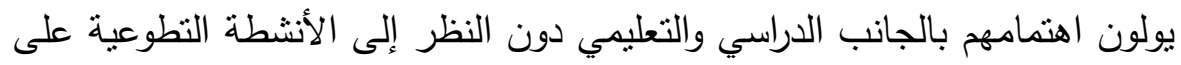
الرغم من أهمية دور الأستاذ الجامعي في تعزيز التطوع لدى طلابه فإهماله لمثل . $\leqslant \vee 0$. 


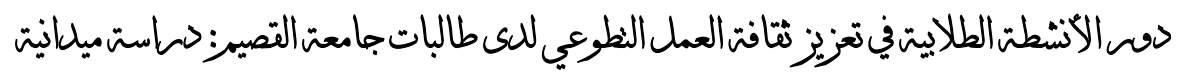

هذه الأنشطة يقلل من أهميتها لديهم، حيث يؤكد (السلطان، 9. . ب) في دراسته بأن

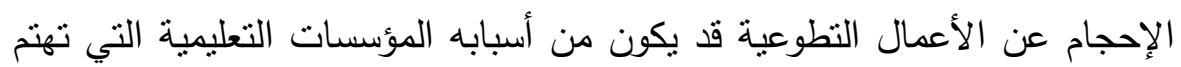

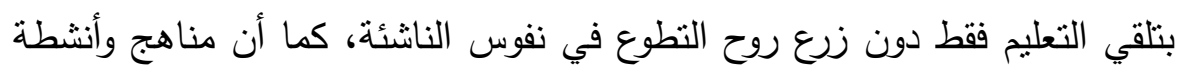

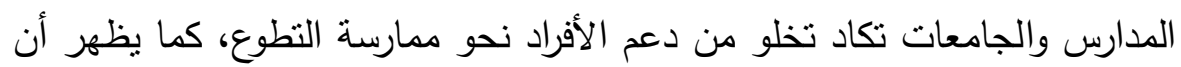
المعوقات ( المرتبطة بالجامعة ككل ) متحققة بدرجة كبيرة إذ بلغ المنوسط الداد

$$
\cdot(r, r \text { ro) }
$$

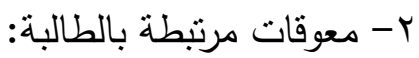

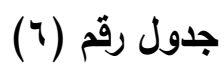

المتوسطات الحسابية والانحرافات المعيارية لاستجابات عينة الدراسة حول المعوقات المرتبطة

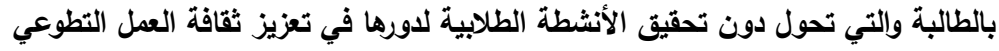

\begin{tabular}{|c|c|c|c|c|c|}
\hline 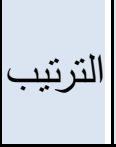 & التحقق & الانحراف & |ل المتوسط & 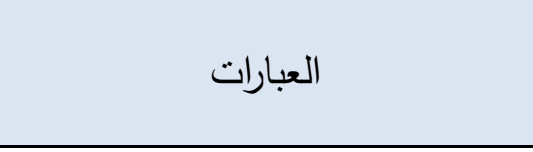 & 5 \\
\hline r & متوسطة & $\cdot, \vee \backslash \wedge$ & $r, Y \leq T$ & قلة وعي الطالبات بمفهوم العمل & 1 \\
\hline 0 & متوسطة & $\cdot, \mathrm{V} \odot \mathrm{V}$ & $r, \cdot V \cdot$ & ضعف الدعم الأسري للطالبات في & r \\
\hline r & كبيرة & $\cdot, 701$ & $r, r \mu q$ & ضعف معرفة الطالبات بمجالات & r \\
\hline$\varepsilon$ & متوسطة & $\cdot, \vee \vee ५$. & $r, 1 \wedge 9$ & ضعف نقة الطالبات في قدرتهن على التطوعي & $\varepsilon$ \\
\hline 1 & كبيرة & $\cdot, 00 Y$ & $r, \uparrow \wedge 9$ & انثغال الطالبات بتقفيذ المهام الدراسية & 0 \\
\hline
\end{tabular}




\section{المركن القومي للبحوث التبويةوالتنمية}

\begin{tabular}{|c|c|c|c|c|}
\hline الترتيب & درجة التحقو & الانحراف & المتوسط & العبارات \\
\hline طة & متود & - , $\leqslant 0$. & $r, r \cdot r$ & تحقيق الأنشطة الطعاتبية لدوتبة بالطالبة والتي تحول دون \\
\hline
\end{tabular}

يتضح من الجدول السابق أن هناك عبارات تحققت بدرجة كبيرة في المعوقات المرتبطة بالجامعة منها "انتغال الطالبات بتتفيذ المهام الدراسية " وتوافق نتيجة هذه العبارة مع ما توصلت إليه دراسة (دوريش، ^ . . ץ) حيث أظهرت بأن الثباب مهتمين بدراستهم أكثر من اهتمامهم بالعمل التطوعي، كذلك دراسة

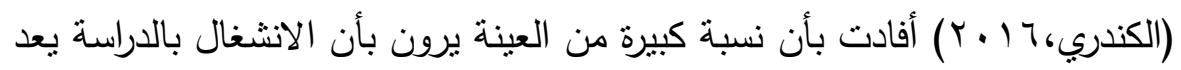

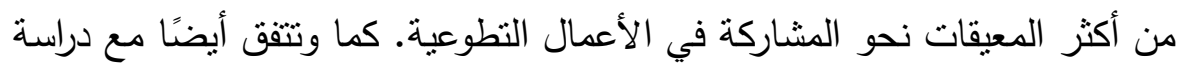

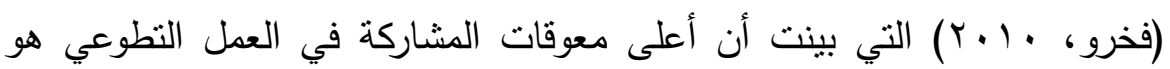
انشغال الطالب الجامعي بالدراسة والامتحانات. كما يتفق أيضًا مع ما توصل إليه

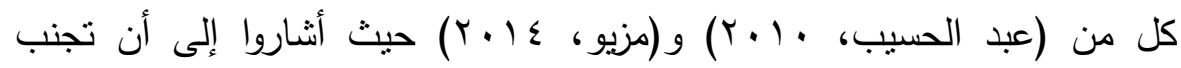
الطالب لممارسة الأنشطة ناتج عن ازدحام جدوله الدراسي وأن كثرة المقررات لا تترك فراغًا ليمارس فيه الطلاب الأنشطة الطلابية. r- معوقات مرتبطة بالمجتمع:

جدول

المتوسطات الحسابية والانحرافات المعيارية لاستجابات عينة الدراسة حول المعوقات المرتبطة

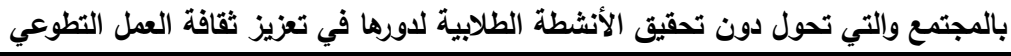

\begin{tabular}{|c|c|c|c|c|c|}
\hline الترتيب & التحقق & الانحراف & المتوسط & العبارات & r \\
\hline
\end{tabular}




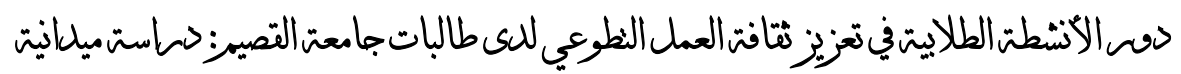

\begin{tabular}{|c|c|c|c|c|c|}
\hline |التزتيب & | - مرجة & الانحراف & المتوسط & العبارات & 5 \\
\hline 1 & |كبيرة & • 7997 & $T, r V Y$ & | ضعف الوعي المجتمعي بأهمية & 1 \\
\hline$r$ & |متوسطة & $\cdot, V Y T$ & $r, Y) \varepsilon$ & والعمل التطوعي في الربط بين القيم الدينية & r \\
\hline$\varepsilon$ & |متوسطة & ד人1, & $r, r \cdot q$ & وجود تبعات وعراقيل تواجه & $r$ \\
\hline 1 & |متوسطة & $\cdot, \vee \vee \vee$ & $r, .9 Y$ & | الاعتقاد بأن خدمة المجتمع من & $\varepsilon$ \\
\hline r & |كبيرة & $\cdot, 791$ & & | الناجحة في الأعمال النماذج والثخصيات & 0 \\
\hline 0 & متوسطة & $\cdot, V T V$ & $r, 1 \wedge 9$ & |لاجتماعي في جذبف شبكات التواصل & 7 \\
\hline \multicolumn{2}{|c|}{ متوسطة } & •, $\leqslant \wedge 9$ & T,YTO & \multicolumn{2}{|c|}{ لدول المعوقات المرتبطة بالمجتمع والتي } \\
\hline
\end{tabular}

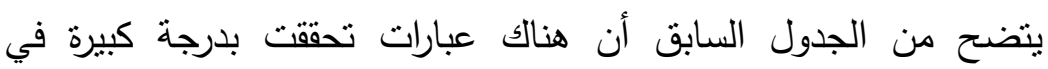
المعوقات المرتبطة بالجامعة وهي عبارة "ضعف الوعي المجتمعي بأهمية العمل 


\section{المركن القومي للبحوث التبويةوالتنمية}

التطوعي" وعبارة "قلة إبراز النماذج والثخصيات الناجحة في الأعمال النطوعية " وتقسر نتيجة العبارة الأولى بأن المجتمع له تأثنير كبير في مدى انتشار هذه الثقافة، حيث إن التقليل من شأن التطوع والمتطوعين يسهم في تقليل فرص مشاركة الطالبات في الأعمال التطوعية فنظرة المجتمع وعاداته وتقاليد هي من تغرس روح

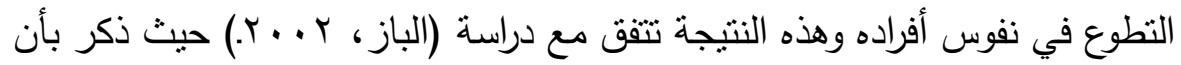
هنالك علاقة بين تقدير المجتمع للتطوع وازدياد مشاركة الأفراد فغياب التقدير

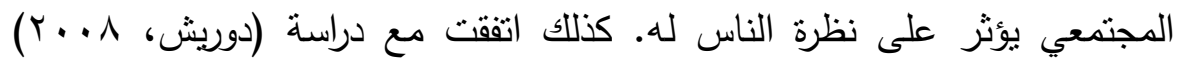
والتي بينت وجود معوقات تحد من مشاركة الثباب في العمل التطوعي أبرزها قلة الوعي بأهمية العمل التطوعي وغياب التقدير المجتمعي حيث أن العادات والتقاليد والقيم التقافية للمجتمع لا تحثهم على الأعمال التطوعية وفيما يخص العبارة الثانية والتي تحققت بدرجة كبيرة حيث أكدت الطالبات على عدم تسليط الضوء للشخصيات البارزة والداعمة للأعمال التطوعية على الرغم من أهمية ذلك فالأفراد بحاجة إلى قدوة يحتذى بها فإظهار منل هذه الشخصيات المهمة لهم وذكر أبرز أعمالهم وإنجازاتهم يلعب دورًا كبيرًا في تثقيفهم وتعزبز التطوع لديهم وتتفق هذه

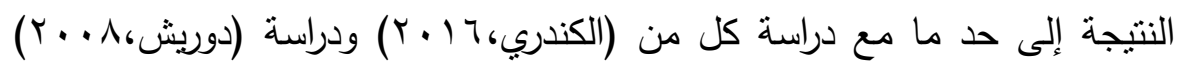

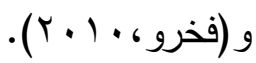

إذن المعوقات التي تحول دون تحقيق الأنشطة الطلابية لدورها في تعزيز ثقافة العمل التطوعي لدى طالبات جامعة القصيم تتحقق بدرجة متوسطة حيث بلغ المتوسط الموزون للارجات الكلية على محور المعوقات في الاستبانة المستخدمة في

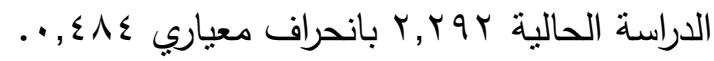

\section{هلخص نتائج الدراسة:}

1. للأنشطة الطلابية دور هام وفعال في تحقيق التربية وتعزيز قيم وثقافات 


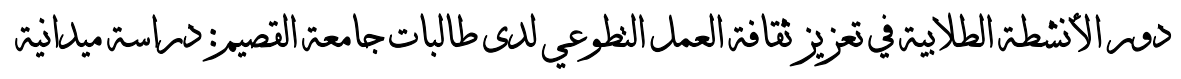

عدة من بينها ثقافة العمل التطوعي وذلك من خلال مجالاتها وأساليبها

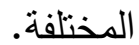

r. أن واقع دور الأنشطة الطلابية في تعزيز ثقافة العمل التطوعي يتحقق

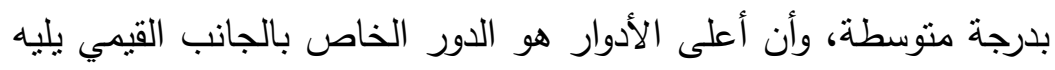
الجانب المعرفي ثم الجانب التطبيقي.

r. المعوقات التي تحول دون تحقيق الأنثطة لدورها في تعزيز ثقافة النطوع الجن

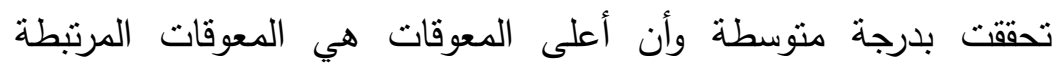

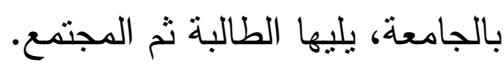

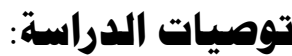

ا. توصي الباحثة بالتركيز على جميع الجوانب المعرفية والقيمية والتطبيقية للأنشطة لما لها من أثز ودور فعال في تعزيز النقافة النطوعية لديهن.

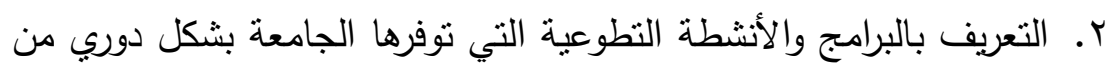
خلال تخصيص أيام تطوعية خلا الفصل الدراسي وذلك لتحقيق توعية أكبر بالثقافة النطوعية.

r. تكثيف البحوث والدراسات العلمية والمسابقات ذات العلاقة بقضايا العمل النطوعي. ء. ضرورة تنظيم زيارات ميدانية لمؤسسات المجتمع للتعرف على برامجها

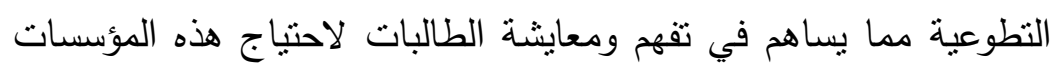
ولإيجاد التعاون فيما بينهم.

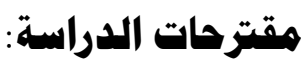

ا ـ إجراء دراسة مماتلة لدور الأنشطة الطلابية في تعزيز تقافة العمل النطوعي

$$
\text { بمراحل أخرى. - مبه }
$$




\section{المركن القومي للبحوث التبويةوالتنمية}

r. إجراء دراسة عن سبل تعزيز ممارسة الأعمال التطوعية لدى طلاب

$$
\text { وطالبات الجامعة. }
$$

r. إجراء دراسة عن المعوقات التي تواجه الجامعة للقيام بدورها في تعزيز

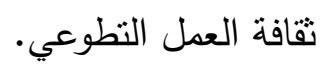

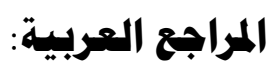

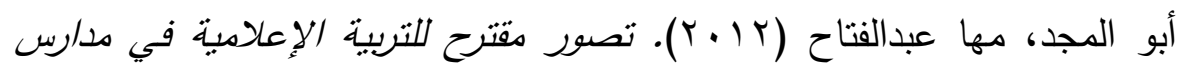
التعليم الثانوي في ضوء بعض الخبرات الدولية. رسالة ماجستير

غير منشورة، كلية التربية، جامعة أسوان، جمهورية مصر العربية. با حارث، أحمد محمد أحمد (9 . . ب). مدى إسهام النشاط الطلابي في تتمبية الحوار لدى طلاب العرحلة الثانوبية. رسالة ماجستير غير منشورة،

كلية التربية، جامعة أم القرى، المملكة العربية السعودية.

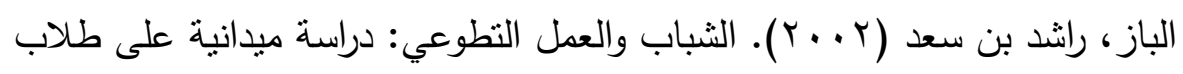
المرحلة الجامعية في مدينة الرياض. مجلة البحوث الأمنية، كلية

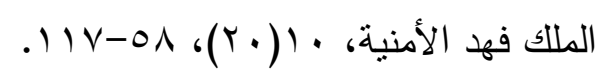

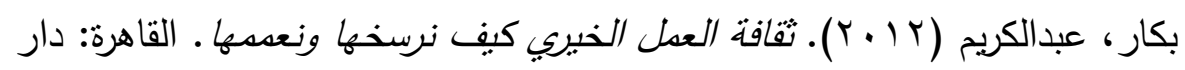

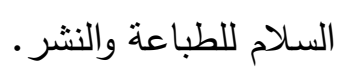

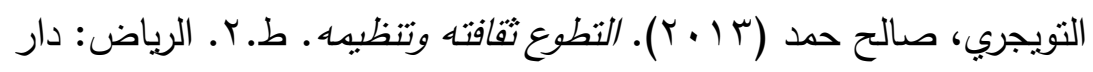

$$
\text { مملكة نجد. }
$$

جامعة القصيم (د.ت). تاريخ الجامعة. تم استرجاعها في تاريخ ابرمضان على:

$$
\text { مناح }
$$

، $) \leqslant T$ 


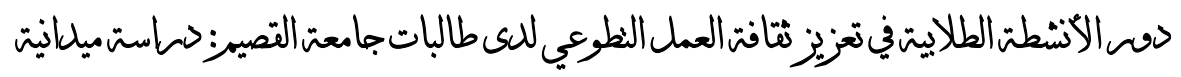

http://www.qu.edu.sa/about/Pages/History-of-

QU.aspx

جبالي، محمد صلاح (Y • Y). ثقافة التطوع والتطوع الثقافي. المجلة- الإصدار الثاني الهيئة الهصرية العامة للكتاب، الهيئة المصرية العامة

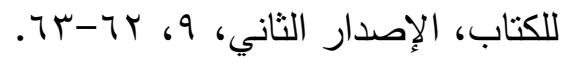

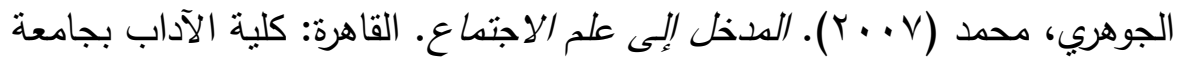

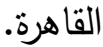

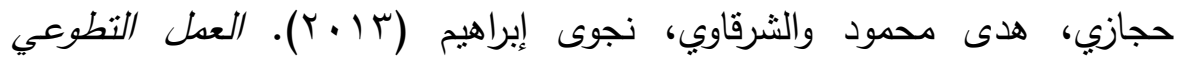
ومؤسسات المجتمع الددني. الرياض: دار الزهراء.

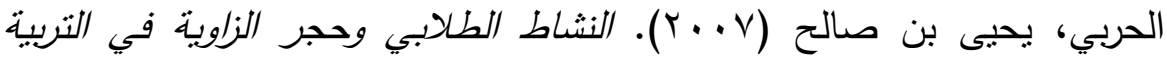
الحديثة. الرياض: دار الحضارة.

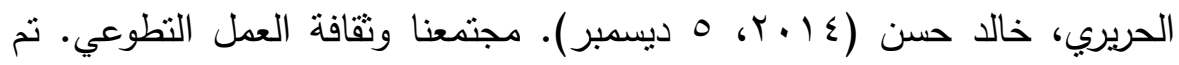

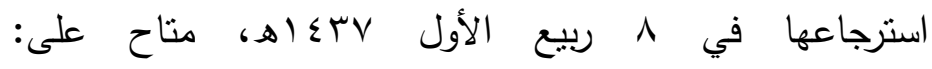
http://www.al-tagheer.com/art29915.html حسين، محمود عبده (ب. . ب). دور الأنثطة الطلابية في إكساب قيم الدشاركة

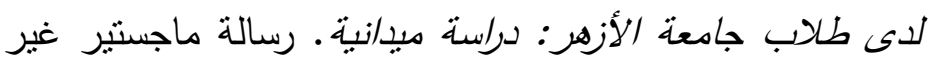
منشورة، كلية التربية، جامعة الأزهر، جمهورية مصر العربية.

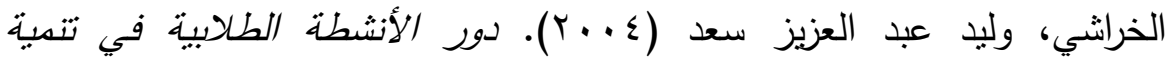

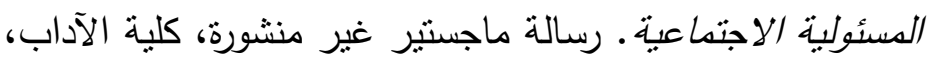
جامعة الملك سعود، المملكة العربية السعودية.

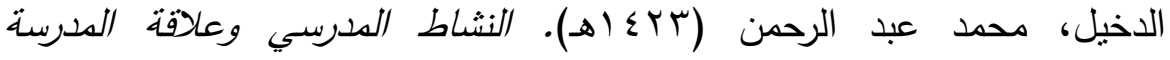
بالهجتمع. الرياض: دار الخريجي للنشر والتوزيع. 


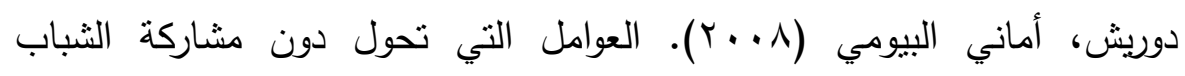
الجامعي في العمل التطوعي تصور مقترح من منظور خدمة الجماعة لاستثارة الثباب للمشاركة في العمل التطوعي. مجلة دراسات في الخدمة الاجتماعية والإنسانية، كلية الخدمة

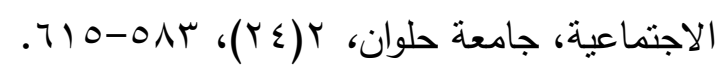
رزق، حنان عبد الحليم (11 (Y). الأنشطة الطلابية وتتمية قيم الانتماء لدى طلاب جامعة المنصور في ضوء متغيرات القرن الحادي والعشرين. مجلة

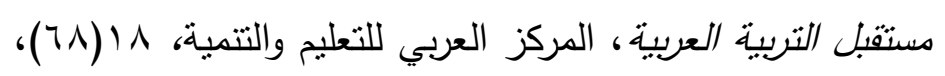
$.11 r-9$

الرفاعي، حامد (10 • Y، Y I أكتوبر). تربويون لتعزيز ثقافة التطوع مطلب تعليمي

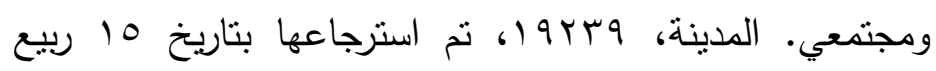
http://www.al- الأول madina.com/node/649030

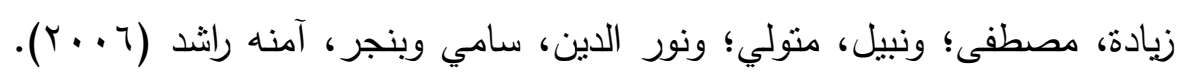
فصول في اجتماعيات التربية. ط. 7، الرياض: مكتبة الرشد.

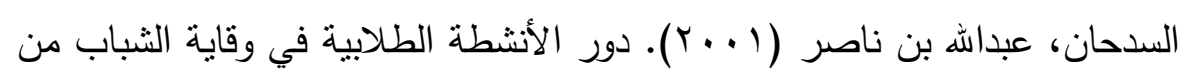

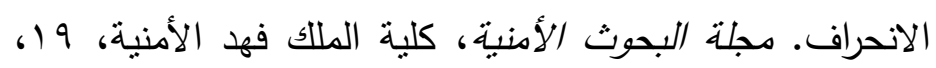

$$
r V-1
$$

السعيد، محمد الذهبي (r (Y). دوافع مشاركة الثباب في الأنشطة النطوعية

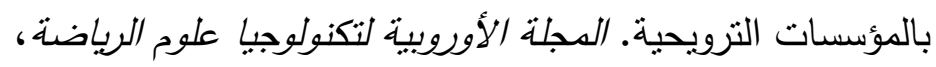

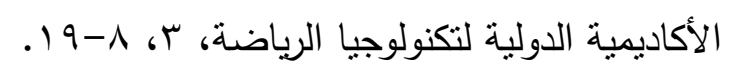




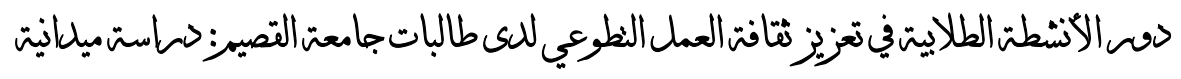

السلطان، فهد بن سلطان (9 . ب). اتجاهات الثباب الجامعي الذكور نحو العمل النطوعي: دراسة تطبيقية على جامعة الملاك سعود. رسالة الخليج

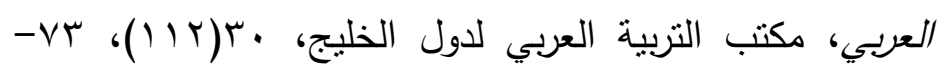
$.1 T V$

شلبي، هناء عبد الغفار محمد (· (Y). برنامج مقترح في الدراسات الاجتماعية

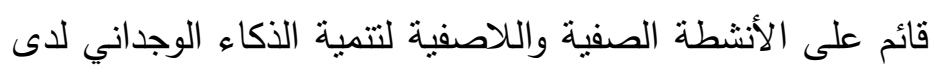

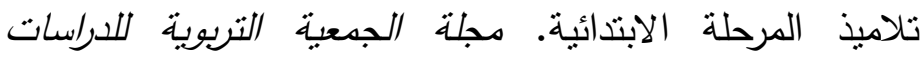

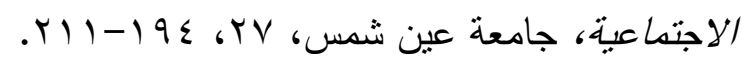

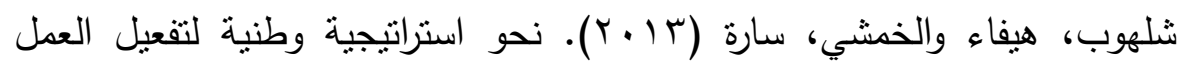

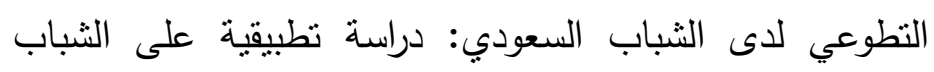

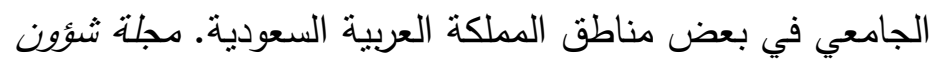

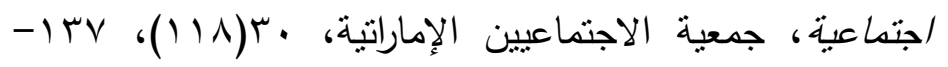
$.1 \wedge \varepsilon$

الصرايرة، خالد أمين (1) (1). (1). كيف نعد أبنائنا للعمل التطوعي واستتُعار

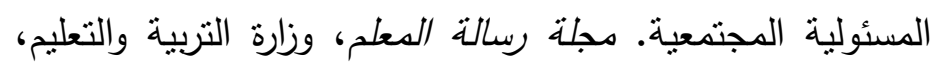

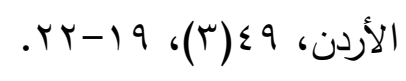

عبد الحسيب، جمال رجب (· (r). ممارسة طلاب جامعة القصيم للأنشطة الطلابية: دراسة ميدانية. مجلة كلية التربية، جامعة عبن شهس،

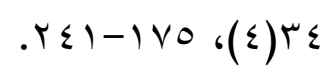

العتوم، منذر سامح (1 . ب). النثاط الددرسي الدعاصر بين النظرية والتطبيق.

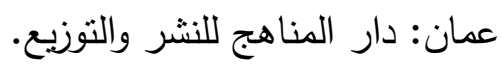


عثمان، رجاء محمود وقمر، عصام توفيق (9 . . ب). النشاط الطلابي. عمان: دار الفكر .

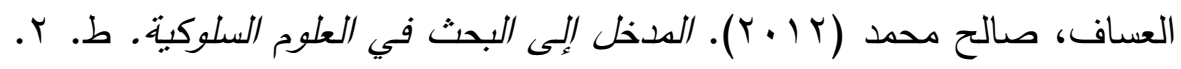
الرياض: دار الزهراء.

عطية، عماد محمد ( • ( ب). المدخل في أصول التربية. الرياض: مكتبة الرشد العالمية.

عنبري، ابتسام حمزة (ج ـ . r). أزمة قضية التطوع. ورقة عمل قدمت إلى المؤتمر السعودي الثاني للتطوع، الرياض، المملكة العربية السعودية.

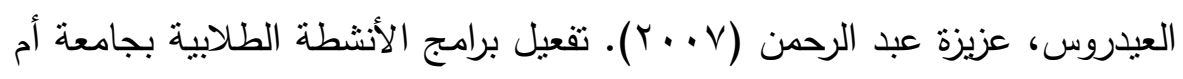

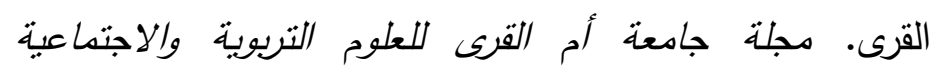
والإنسانية، 9 (1) (1)، 9 (1)

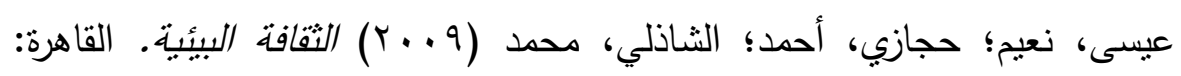
الدار العربية للنشر والتوزيع.

فخرو، عبد الناصر عبد الرحيم (· ( • ( ). تعزيز ثقافة العمل التطوعي لدى طلاب جامعة الكوبت: تصور مقترح. مجلة العلوم التربوبية، معهذ

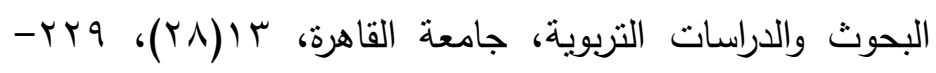
ו

القحطاني، سالم علي (ع ( r). معايير الأنشطة التعليمية ومدى انطباقها على أنشطة مقرر الحديث للصف الأول متوسط. مجلة التربية، جامعة

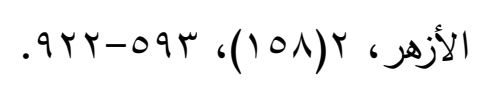




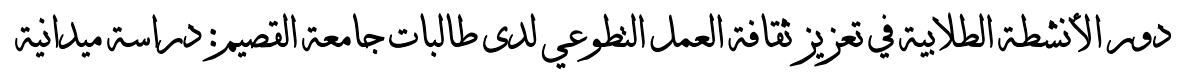

القطب، سمير (T . . Y). واقع ومعوقات الأنشطة الطلابية في جامعة طيبة.

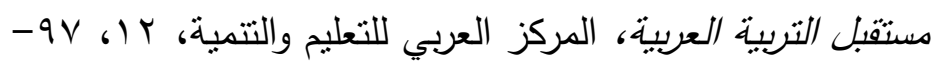

TTY

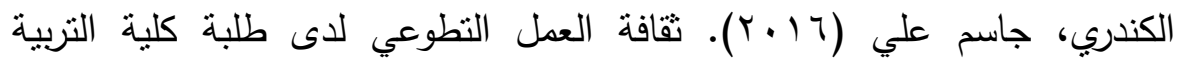

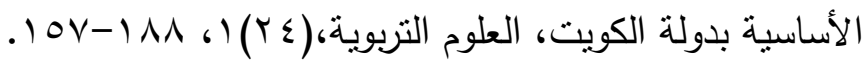

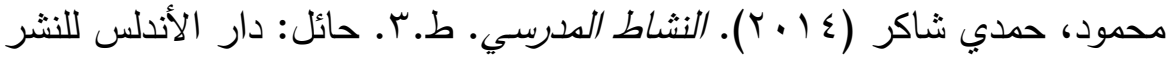

$$
\text { والتوزيع. }
$$

مركز مداد الدولي للأبحاث والدراسات ( • • r، جr بناير ). العمل التطوعي البيئي.

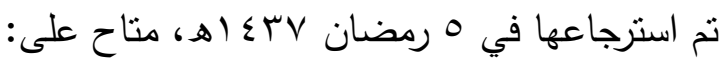
http://www.medadcenter.com/articles/1583

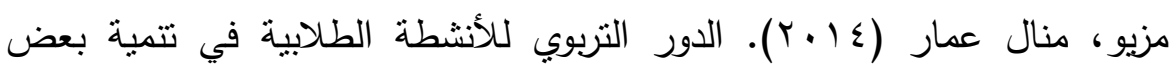

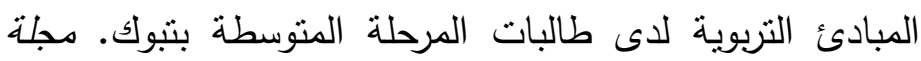
العلوم التربوية، معهد البحوث والدراسات التربوية، جامعة القاهرة،

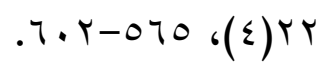

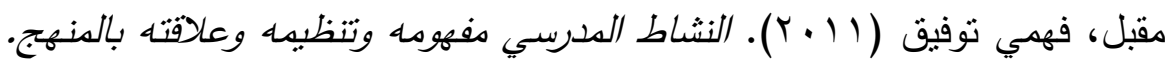
عمان: كلية العلوم والآداب جامعة البتراء.

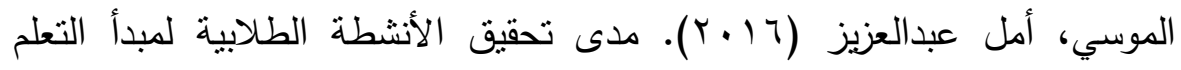

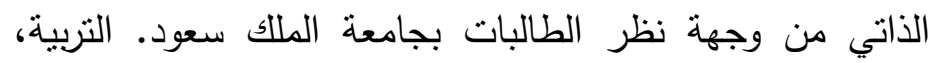

$$
\text { .091-1.07V(17V) }
$$

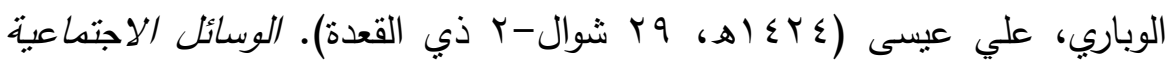
لاستقطاب الهنطوعين. اللقاء السنوي للجهات الهنات الخيرية الرابع

بالمنطقة الثرقية، المملكة العربية السعودية.

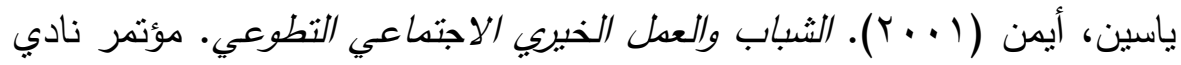

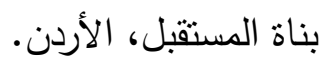




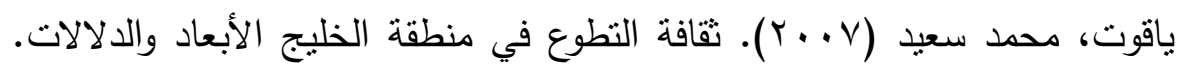

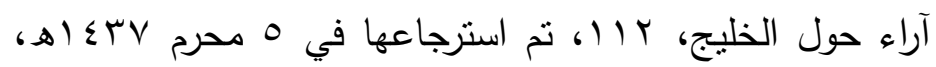

$$
\text { مناح على: }
$$

http://araa.sa/index.php?view=article\&id=1610:2014-07-1406-37-00\&Itemid=172\&option=com_content اليحيى، سليمان بن عبدالعزبز (Y (Y). دليل طلاب جامعة القصبم. القصيم: جامعة القصيم.

اليوسف، عبد الله (0 ب ج). ثقافة العهل التطوعي. جده: الراية للتنمية الفكرية.

Carlson, J. (2013). The Call to Serve: A Survey Study Exploring the Motives of Volunteers in Higher Education. Ph.D. Thesis, Northeastern University, Boston, USA.

Massoni, E. (2011). Positive Effects of Extra Curricular Activities on Students. ESSA/, College of Dubage, 9(27), 1-4. 